\title{
Process Simulation of Biomass Gasification Integrated With a Solid Oxide Fuel Cell Stack
}

Wayne Doherty

Technological University Dublin, wayne.doherty@tudublin.ie

Anthony Reynolds

Technological University Dublin, anthony.reynolds@tudublin.ie

David Kennedy

Technological University Dublin, david.kennedy@tudublin.ie

Follow this and additional works at: https://arrow.tudublin.ie/engschmecart

Part of the Energy Systems Commons, and the Thermodynamics Commons

\section{Recommended Citation}

Doherty,W.,Reynolds, A.Kennedy, D. (2015) Process Simulation of Biomass Gasification Integrated with a Solid Oxide Fuel Cell Stack. Journal of Power Sources 2015;277:292-303. doi:10.1016/

j.jpowsour.2014.11.125

This Article is brought to you for free and open access by the School of Mechanical and Design Engineering at ARROW@TU Dublin. It has been accepted for inclusion in Articles by an authorized administrator of ARROW@TU Dublin. For more information, please contact arrow.admin@tudublin.ie, aisling.coyne@tudublin.ie, gerard.connolly@tudublin.ie.

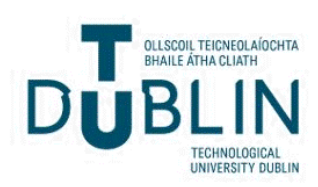




\title{
Process simulation of biomass gasification integrated with a solid oxide fuel cell stack
}

\author{
Wayne Doherty ${ }^{a, b, *}$, Anthony Reynolds ${ }^{a, b}$, David Kennedy ${ }^{a, b}$

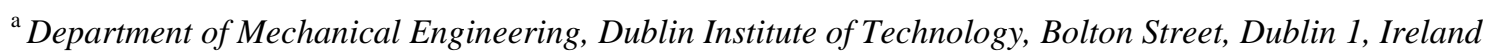 \\ ${ }^{\mathrm{b}}$ Dublin Energy Lab, Focas Institute, Dublin Institute of Technology, Dublin 8, Ireland
}

\section{HIGHLIGHTS}

- A cathode recycle or electric heater for syngas preheating is not attractive.

- Thermal integration between the gasifier and fuel cell is desirable.

- Lowering the syngas preheat temperature is highly recommended.

- High temperature syngas cleaning reduces plant complexity and improves performance.

- Gasification air preheating is more attractive than gasification steam superheating.

\begin{abstract}
Biomass gasification-solid oxide fuel cell (BG-SOFC) combined heat and power (CHP) systems are of major interest in the context of climate change mitigation, energy security and increasing energy efficiency. Aspen Plus is employed to simulate various BG-SOFC CHP systems. The aim of the research work is to investigate the technical feasibility of these systems and to study the influence of important operating parameters and examine integration options. Systems based on dual fluidised bed steam gasification and tubular SOFC technologies are modelled. The cathode recycle and electric heater integration options are not attractive in comparison to the base case anode recycle system. Thermal integration, i.e. using SOFC flue gas as gasifier oxidant, is desirable. Lowering the syngas preheat temperature (prior to SOFC anodes) is highly recommended and is more practical than lowering the cathode air preheat temperature. Results of the parametric study indicate that: steam to carbon ratio and biomass moisture content should be as low as possible; fuel utilisation factor can change the mode of operation of the plant (focus on electricity or heat); high temperature syngas cleaning is very attractive; gasification air preheating is more attractive than gasification steam superheating. High efficiencies are predicted, proving the technical feasibility of BG-SOFC CHP systems.
\end{abstract}

Keywords: Biomass gasification, Tubular solid oxide fuel cell, Dual fluidised bed, Combined heat and power, Aspen Plus, Modelling 
* Corresponding author. Tel.: +353 1 4022976; fax: +35314023991.

E-mail addresses: wayne.doherty@dit.ie (W. Doherty), anthony.reynolds@dit.ie (A. Reynolds), david.kennedy@dit.ie (D. Kennedy).

\section{Nomenclature}

Roman letters

BG-SOFC Biomass gasification-solid oxide fuel cell

CGE Cold gas efficiency

CHP Combined heat and power

$c_{p} \quad$ Specific heat capacity, $\mathrm{kJ} \mathrm{kg}^{-1} \mathrm{~K}^{-1}$

CZ Combustion zone

$\mathrm{db} \quad$ Dry basis

DFB Dual fluidised bed

FICFB Fast internally circulating fluidised bed

GZ Gasification zone

HHV Higher heating value, $\mathrm{MJ} \mathrm{m}^{-3}$ or $\mathrm{kJ} \mathrm{kg}^{-1}$

$j \quad$ Current density, $\mathrm{A} \mathrm{m}^{-2}$ or $\mathrm{mA} \mathrm{cm}^{-2}$

LHV Lower heating value, $\mathrm{kJ} \mathrm{kg}^{-1}$

$\dot{m} \quad$ Mass flow rate, $\mathrm{kg} \mathrm{s}^{-1}$

$P_{\text {biomass }} \quad$ Biomass input power, $\mathrm{kW}$

$P_{e l, A C} \quad$ Electrical AC power, $\mathrm{kW}$

pp Percentage points

$P_{\text {parasitic }} \quad$ Total parasitic power, $\mathrm{kW}$

ppmv Volumetric parts per million

$Q \quad$ Maximum recoverable heat, $\mathrm{kW}$

STBR Steam to biomass ratio

STCR Steam to carbon ratio

$T_{g} \quad$ Gasification temperature, ${ }^{\circ} \mathrm{C}$

$U_{a} \quad$ Air utilisation factor 
$U_{f} \quad$ Fuel utilisation factor

wb Wet basis

$\mathrm{ZnO} \quad$ Zinc oxide

Greek letters

$\Delta T \quad$ Temperature difference

$\eta_{C H P, n e t} \quad$ Plant net AC CHP efficiency (LHV basis)

$\eta_{e l, n e t} \quad$ Plant net AC electrical efficiency (LHV basis)

$\eta_{\text {SOFC }} \quad$ SOFC AC efficiency (LHV basis)

Subscripts

biomass Biomass input fuel

fuel Input gaseous fuel to SOFC stack

gas $\quad$ Syngas

\section{Introduction}

The efficient utilisation of biomass resources is of utmost importance if it is to replace a significant proportion of fossil fuels. Traditional biomass combustion based technologies achieve low electrical efficiencies at small scale (20-25\%) and therefore cannot compete with fossil fuels. Scale is limited by biomass supply logistics. The systems examined in this research work are at a relatively small scale of $120 \mathrm{~kW}$ DC power output (see section 2.2 for additional details). Biomass gasification coupled with solid oxide fuel cells (BG-SOFC) offer much higher efficiencies. These systems offer highly efficient renewable energy, are modular in nature making them ideal for decentralised combined heat and power (CHP) applications and as a result have recently gained much attention [1-9]. For a comprehensive list and description of research on BG-SOFC systems, refer to Nagel [4] and Doherty [10]. Biomass gasification and SOFCs are well matched as they are thermally compatible (similar operating temperatures $\sim 800$ to $1,000{ }^{\circ} \mathrm{C}$ ) and thus offer many integration options. Fig. 1 displays a simplified block diagram of a BG-SOFC CHP system. These plants are still being developed and there is a need for accurate process simulation models that can aid in the design and understanding of these systems. 


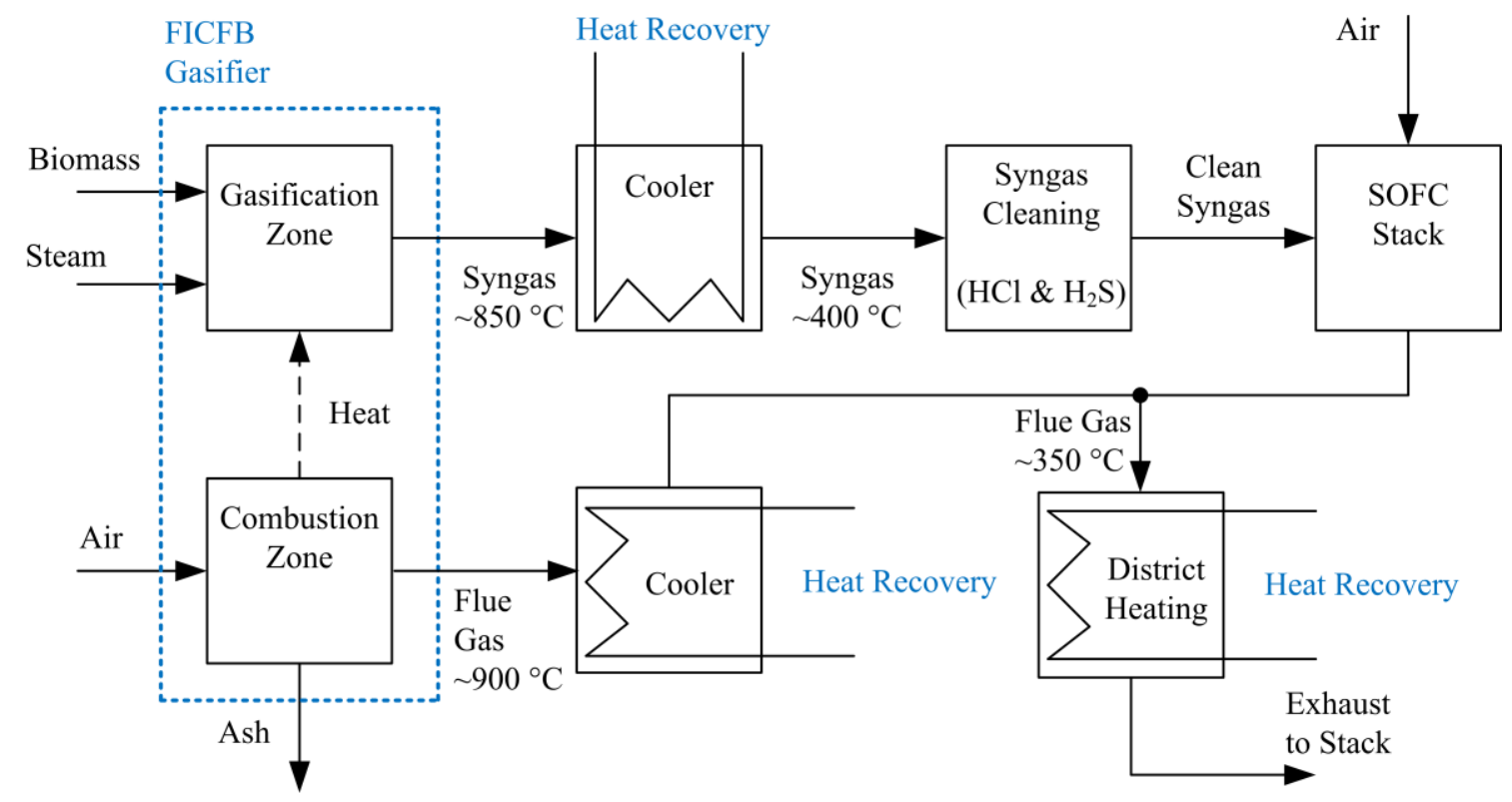

Fig. 1. Simplified block diagram of a BG-SOFC CHP system.

Gasification is a thermochemical process in which a carbonaceous fuel is converted to a combustible gas. This combustible gas is known as syngas (from synthetic or synthesis gas) and consists of hydrogen $\left(\mathrm{H}_{2}\right)$, carbon monoxide $(\mathrm{CO})$, methane $\left(\mathrm{CH}_{4}\right)$, carbon dioxide $\left(\mathrm{CO}_{2}\right)$, water vapour $\left(\mathrm{H}_{2} \mathrm{O}\right)$, nitrogen $\left(\mathrm{N}_{2}\right)$, higher hydrocarbons and impurities such as tars, ammonia $\left(\mathrm{NH}_{3}\right)$, hydrogen sulphide $\left(\mathrm{H}_{2} \mathrm{~S}\right)$ and hydrogen chloride $(\mathrm{HCl})$. The process occurs when a controlled amount of oxidant (e.g. pure $\mathrm{O}_{2}$, air, steam) is reacted at high temperatures with available carbon in a fuel within a gasifier. Air gasification produces a syngas with low energy content, around 4-7 $\mathrm{MJ} \mathrm{m}^{-3}$ higher heating value (HHV), while pure $\mathrm{O}_{2}$ and steam blown processes result in a syngas with a heating value in the range of $10-18 \mathrm{MJ} \mathrm{m}^{-3}$ (HHV) [11].

A fuel cell consists of two electrodes separated by an ion conducting electrolyte. Fuel is supplied to the negative electrode (anode) and oxidant to the positive electrode (cathode). Fuel cells convert the chemical energy contained in a fuel directly to electrical energy via electrochemical reactions, making them a highly efficient energy conversion device. SOFCs can utilise a wide spectrum of fuels (natural gas, coal and biomass syngas, liquid fuels including methanol and kerosene) due to their high operating temperature.

The aim of this research work is to investigate the technical feasibility of BG-SOFC CHP systems and to study the influence of important operating parameters and examine integration options. This aim is accomplished through the development of zero-dimensional process simulation models using Aspen Plus. The models are isothermal, steady state and based on Gibbs free energy minimisation (temperature approach method employed to adjust the gasifier output syngas composition, i.e. restricted equilibrium model type). 
No Aspen Plus models of the selected BG-SOFC technologies (see section 2) were found in the literature; therefore, the models conceived in this work are original. This article presents new results from an extensive parametric study and detailed investigations (e.g. impact of anode/cathode recycle, thermal integration of gasifier and fuel cell, etc.). Based on a literature review, a suitable syngas cleaning and reforming system configuration is proposed. Careful consideration was given to syngas humidification (carbon deposition prevention), heat recovery and parasitic power requirements as these have been frequently overlooked in previous BG-SOFC studies. The developed process simulation models have been validated against published plant or experimental data.

\section{Technology description}

\subsection{Biomass gasification technology}

A special type of fluidised bed gasifier known as the dual fluidised bed (DFB) utilises steam as gasification medium in order to produce high quality syngas (high energy content, high $\mathrm{H}_{2}$ and $\mathrm{N}_{2}$ free) suitable for

applications such as fuel cells. This type of gasifier is based on the principle that separation of the gasification and combustion zones (GZ and $\mathrm{CZ}$ ) will avoid $\mathrm{N}_{2}$ dilution of the syngas (due to combustion of fuel with air). These gasifiers are known as indirectly heated or allothermal gasifiers as the GZ and CZ are separated and heat is transferred between them by means of circulating bed material, heat pipes or some alternative method. The fast internally circulating fluidised bed (FICFB) gasifier is the most developed and most proven DFB gasifier (Güssing CHP plant, Austria) and was therefore selected for this study. A brief description of its operation is provided in the following paragraph; refer to Doherty et al. [12] and Doherty [10] for additional information.

In a FICFB gasifier, the biomass fuel is gasified in a steam blown bubbling fluidised bed reactor (GZ). Residual char leaves the GZ with bed material and enters a circulating fluidised bed riser (CZ) where it is combusted with air. After separation from the flue gas in a cyclone, the heated bed material flows back to the GZ. This bed material provides the heat required to drive the endothermic steam gasification reactions which produce the syngas. The FICFB gasifier operates at atmospheric pressure.

\subsection{Solid oxide fuel cell technology}

The Siemens Power Generation Inc. tubular SOFC was chosen for the following reasons: advanced stage of development; most reliable and robust design [4]; well proven (120 kW DC power unit operated for over 36,000 hours on natural gas [13]); operational data available for model validation; low performance degradation [14] 
and long stack lifetime. The main drawback to this design is low power densities caused by long current flow paths and thus high ohmic voltage losses [4]. Low power density means large plant footprint and weight [15], which limits the scale of these plants to $\sim 2$ MW DC power. In this research work it was assumed that four and eight $120 \mathrm{~kW}$ stacks could be connected to increase the scale of the plant to $\sim 500 \mathrm{~kW}$ and $\sim 1 \mathrm{MW}$ DC power output respectively (note: the results presented in this article are all for a single $120 \mathrm{~kW}$ DC power output stack). The $120 \mathrm{~kW}$ stack consists of 1,152 cells in 48 bundles of 24 cells each [16]. Refer to Doherty et al. [17, 18] and Doherty [10] for details on the operation of the $120 \mathrm{~kW}$ stack (stream flow diagram, etc.).

The US Department of Energy SECA program is the main SOFC development program. Fuel cell manufacturers such as Siemens are involved and one of the goals is to reduce the cost of production to 400 $\$ / \mathrm{kWe}$. It was recognised that the standard Siemens tubular SOFC could not meet the cost and performance targets. A new flattened tube design was investigated. Higher power density is realised because ribs act as bridges for current flow, shortening the current flow path and reducing ohmic loss. In 2008 Siemens began working on the next generation of high power density tubular SOFC, the delta (triangular tube) SOFC [4]. Demonstration of a MWe class module based on the delta SOFC was planned for 2012 but it appears that all work has stopped. Siemens ceased work on the development of their tubular SOFC technology ca 2010. Siemens found the timeframe to bring the technology to commercialisation did not fit with its profit targets [19].

\subsection{Syngas conditioning technology}

Syngas produced by gasification of biomass may contain the following impurities/contaminants that must be removed or converted prior to the SOFC stack: particulates, alkali, chlorides, sulphur compounds, tars and nitrogen compounds. In this section, a syngas cleaning and reforming system configuration suitable for BGSOFC applications is proposed (see Fig. 2).

Warm gas cleaning technologies (operating at $\sim 400{ }^{\circ} \mathrm{C}$ ) were selected rather than simplistic well proven cold gas cleaning technologies (scrubbers, etc.) because a major advantage of biomass gasifier SOFC integration is that they operate at comparable temperatures and syngas cooling to low temperature would have considerable efficiency penalty. Hot syngas cleaning technologies are not yet sufficiently developed to meet the strict SOFC cleaning requirements. The first step is tar reduction within the gasifier, which is achieved through temperature control (sufficiently high at $\sim 850^{\circ} \mathrm{C}$ ) and the use of catalytically active bed material (olivine). Next the syngas passes through a cyclone filter for removal of coarse particulates at high temperature. The syngas is then cooled to a temperature suitable for fine particulates, alkali, $\mathrm{HCl}$ and $\mathrm{H}_{2} \mathrm{~S}$ cleaning $\left(\sim 400^{\circ} \mathrm{C}\right)$. A robust syngas cooler 
will be required for smooth operation as alkali will condense to form particulates that may deposit and cause blockage/corrosion problems within the cooler. An additional cyclone filter may be needed after cooling prior to the candle filter in order to prevent plugging (coarse particulates may have formed due to alkali condensation). To inhibit carbon deposition in pipes and downstream equipment the syngas is humidified with steam. Fine particulates and alkali are removed by means of a sintered metal candle filter. An alkali getter such as bauxite should not be necessary as the syngas is cooled to $400{ }^{\circ} \mathrm{C}$ and therefore the alkali should condense out. The next step is $\mathrm{HCl}$ cleaning in a sodium carbonate bed, followed by $\mathrm{H}_{2} \mathrm{~S}$ removal in a zinc oxide $(\mathrm{ZnO})$ bed. Finally, the syngas enters the SOFC stack where internal reforming occurs (nickel catalyst bed); converting the tars, hydrocarbons and decomposing the $\mathrm{NH}_{3}$ prior to the SOFC anodes.

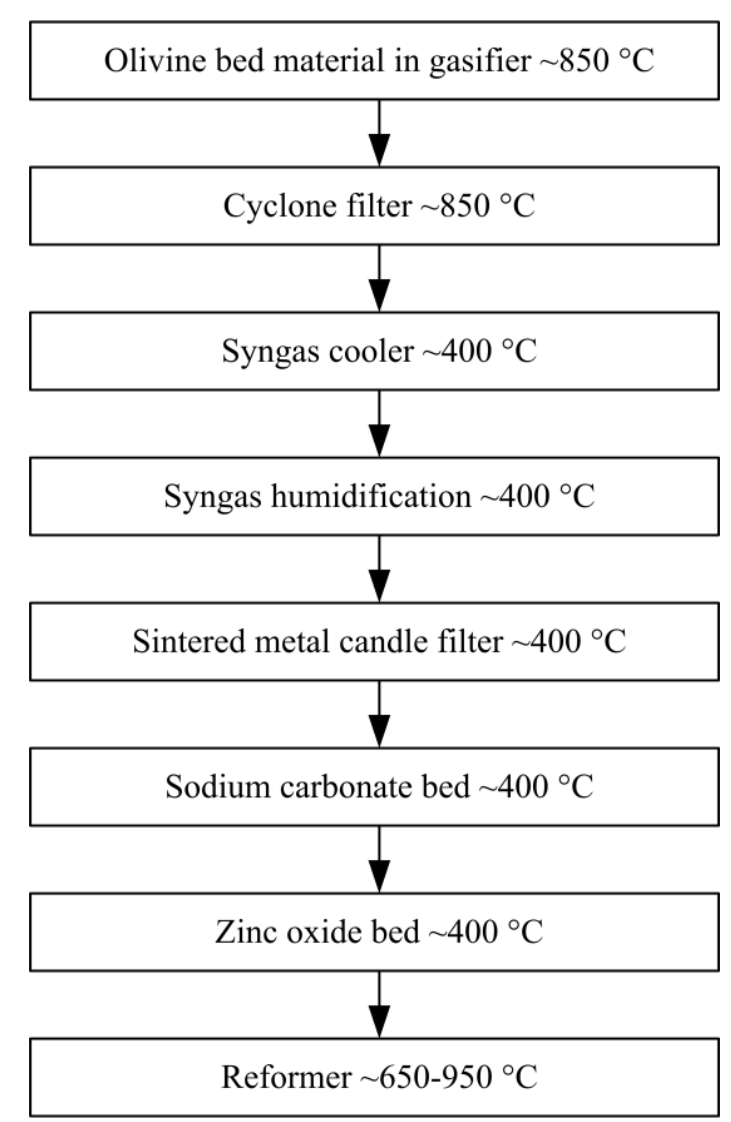

Fig. 2. Proposed syngas cleaning and reforming system.

\section{System modelling}

The process simulation software package Aspen Plus was utilised to model the BG-SOFC CHP systems. Standalone models of the DFB gasifier and SOFC stack were developed and validated against published plant or experimental data. Details on these models are published elsewhere $[12,17,18]$. The standalone models were 
integrated considering syngas conditioning, heat recovery and balance of plant components and various system configurations were evaluated. These system configurations are described in this section. Unless stated otherwise, all combined system model inputs match those reported for the standalone models $[12,17,18]$.

\subsection{System 1 - base case with anode recycle}

The system 1 (base case system) Aspen Plus flowsheet is displayed in Fig. 3. The system comprises the DFB gasifier, SOFC stack, syngas cleaning equipment, heat recovery system (syngas cooler, steam generator, air preheaters, etc.) and balance of plant components (compressors, pumps, etc.). The modelling approach to both the gasifier and the SOFC match the standalone models $[12,17,18]$. For additional information on the FICFB gasifier and SOFC stack unit operation blocks (Fig. 3) the reader is referred elsewhere [12, 17, 18]. It was necessary to make changes to the layout and model inputs and these will be explained.

The 'BIOMASS' stream mass flow rate is set by one of two ways depending on whether the SOFC current density $\left(j\right.$ in $\mathrm{A} \mathrm{m}^{-2}$ or $\mathrm{mA} \mathrm{cm} \mathrm{cm}^{-2}$ ) is variable (constant power output) or constant (variable power output). The two approaches were necessary because during the current density sensitivity analysis (section 4.3.1) $j$ must be specified, i.e. it is constant. During all other sensitivity analyses $j$ is calculated, i.e. it is variable. When $j$ is variable a design specification block varies the biomass mass flow rate until the DC power equals the desired value $(120 \mathrm{~kW})$. Equations were employed to determine $j$, after which the voltage and power were calculated (implemented using Fortran code). This calculation sequence was repeated until the DC power was equal to the desired value. For specified $j$, a design specification block utilises equations to determine the syngas flow rate at the SOFC inlet ('SYNGAS2' stream) required to achieve that $j$ value. The design specification block varies biomass mass flow rate until this $j$ is achieved. The equations and Fortran code may be found in Doherty [10]. The biomass composition and heating value (typical of wood chip) are reported in Doherty et al. [12].

The stream 'COMBAIR' is fed to a Compr block titled 'COMP3', which compresses the combustion air to a pressure of 1.094 bar. All compressors were assumed to have mechanical and isentropic efficiencies of $95 \%$ and $75 \%$ respectively. The compressed combustion air enters the combustion air preheater; a HeatX block named 'HEX1'. All heat exchangers were specified as countercurrent with the shortcut calculation option selected. The 'HEX1' cold stream outlet temperature was set at $450{ }^{\circ} \mathrm{C}$ (combustion air preheat temperature). The stream 'HOTAIR' is then fed to the $\mathrm{CZ}$ of the gasifier (block 'COMB') where char combustion takes place. The $\mathrm{CZ}$ temperature was assumed $70{ }^{\circ} \mathrm{C}$ above the gasification temperature $\left(T_{g}\right)$ of $850{ }^{\circ} \mathrm{C}[20]$. 


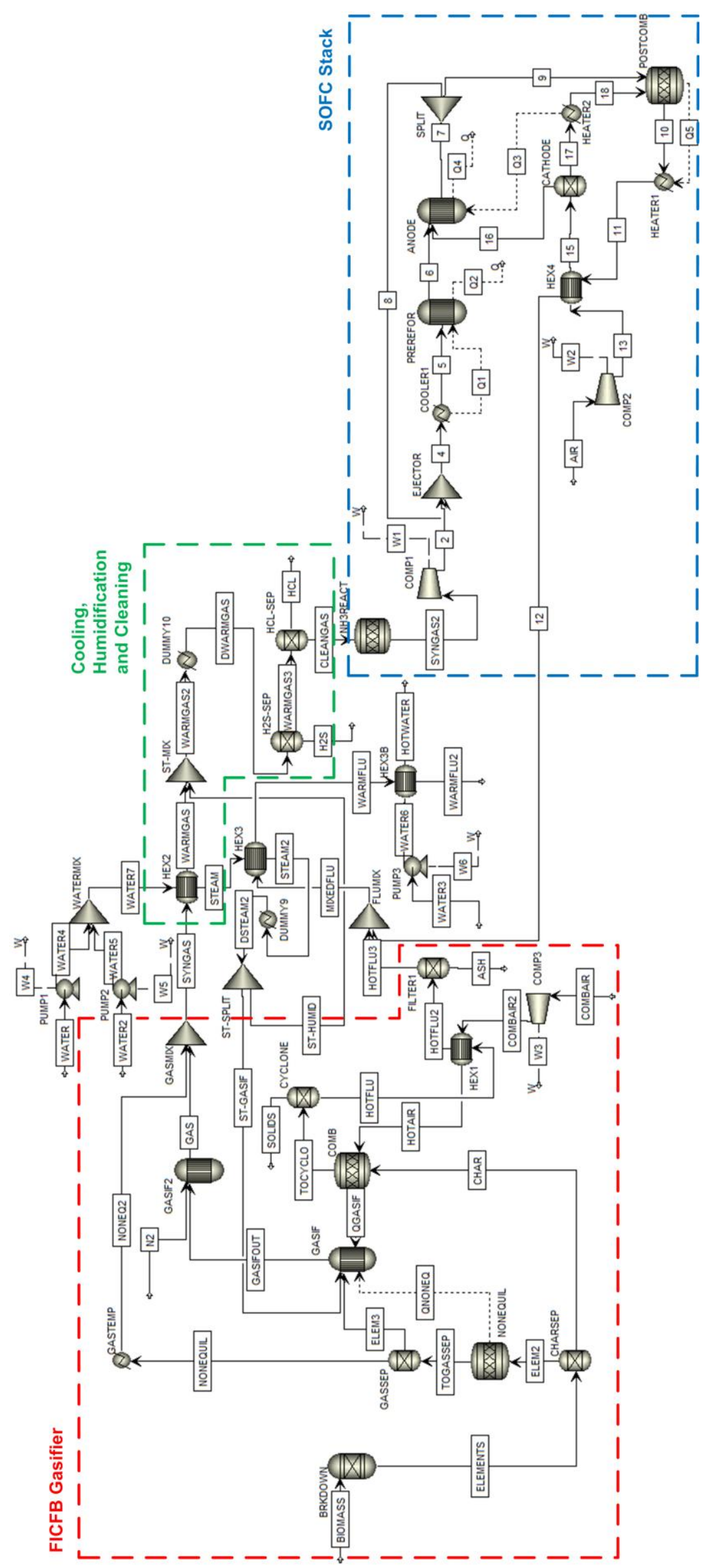

Fig. 3. System 1 Aspen Plus flowsheet. 
Gasification steam at $350{ }^{\circ} \mathrm{C}$ is generated utilising the heat recovered from the syngas (syngas cooler 'HEX2') and the mixed flue gas (steam superheater 'HEX3'). A design specification block is employed to calculate and set the mass flow rate of gasification steam using a steam to biomass ratio (STBR). STBR is defined as the mass flow rate of biomass moisture plus the injected steam divided by the dry biomass mass flow rate. The stream 'WATER' mass flow rate is varied until the STBR equals 0.75.

The 'WATER2' stream mass flow rate is set by a design specification block and is dependent on the steam to carbon ratio (STCR) required to prevent carbon deposition after syngas cooling and during cleaning. STCR is defined as the molar ratio of steam to combustible carbon [21]. STCR was kept as low as possible at 1.85 due to the SOFC anode recycle, used for syngas preheating, which results in a much greater STCR at the SOFC inlet $($ SOFC STCR $=4.57)$. The pressure of 'WATER' and 'WATER2' is increased to 5 bar using pumps; all pumps were assumed to have a pump efficiency of $75 \%$. The two streams are then mixed and pass through the syngas cooler where the mixed stream temperature is increased to the saturation temperature and the syngas temperature drops to $\sim 408{ }^{\circ} \mathrm{C}$. This syngas temperature was chosen because the operating temperature of the syngas cleaning equipment is $400{ }^{\circ} \mathrm{C}$ and syngas temperature decreases to this after humidification (Mixer block 'ST-MIX'). The saturated steam is superheated to $350{ }^{\circ} \mathrm{C}$ by the 'MIXEDFLU' stream in the block 'HEX3'. The mixed steam is split into gasification steam (directed to GZ of the gasifier) and humidification steam (mixed with syngas to increase STCR to 1.85). This is accomplished using a calculator block that sets the block 'ST-SPLIT' split fraction.

The following equation was used to calculate the maximum recoverable heat $(Q)$, i.e. the heat that could be recovered if the flue gas (stream 'WARMFLU') was cooled to standard temperature: $Q=\dot{m} c_{p} \Delta T$. Where $\dot{m}$ is stream mass flow rate in $\mathrm{kg} \mathrm{s}^{-1}, c_{p}$ is the specific heat capacity of the stream in $\mathrm{kJ} \mathrm{kg}^{-1} \mathrm{~K}^{-1}$ and $\Delta T$ is the stream temperature minus $25^{\circ} \mathrm{C}$.

The humidified syngas 'WARMGAS2' enters the cleaning system. Some cleaning steps are omitted; e.g. the cyclone filter and sintered metal candle filter for particulates and alkali removal. These steps were not modelled as the model does not consider particulates or alkali. $\mathrm{H}_{2} \mathrm{~S}$ is removed using a $\mathrm{ZnO}$ bed. A value of 0.3 volumetric parts per million (ppmv) for $\mathrm{H}_{2} \mathrm{~S}$ after the $\mathrm{ZnO}$ bed was assumed [22]. $\mathrm{HCl}$ content is lowered to 1 ppmv by means of a sodium carbonate bed $[22,23]$. The beds were modelled as separators with the split fractions set using two design specification blocks that vary split fraction until $\mathrm{H}_{2} \mathrm{~S}$ and $\mathrm{HCl}$ concentrations equal 0.3 and 1 ppmv respectively in the 'CLEANGAS' stream. Tars were not considered in the model. It was assumed that they would not cause problems as the syngas temperature was maintained above the tar dew point temperature (150- 
$\left.350{ }^{\circ} \mathrm{C}\right)[4,22]$. The tars would be catalytically reformed in the SOFC pre-reformers along with the lighter hydrocarbons. $\mathrm{NH}_{3}$ was not removed as it is considered a fuel. Conversion of $\mathrm{NH}_{3}$ in a SOFC is a two stage process: decomposition into nitrogen and hydrogen followed by oxidation of hydrogen to water [24]. The first stage of this process was simulated in the 'NH3REACT' RStoic block, where the reverse $\mathrm{NH}_{3}$ formation reaction $\left(\mathrm{NH}_{3} \rightleftharpoons 0.5 \mathrm{~N}_{2}+1.5 \mathrm{H}_{2}\right)$ was specified with $100 \% \mathrm{NH}_{3}$ conversion. The block temperature was set to the cleaning temperature $\left(400{ }^{\circ} \mathrm{C}\right)$ using a calculator block. The second stage of the process occurs within the SOFC stack when the $\mathrm{H}_{2}$ is converted on the anodes.

An anode recycle is employed to preheat the syngas prior to the SOFC pre-reformers. A design specification block varies the split fraction of the block 'SPLIT' until the temperature of stream 4 equals $800{ }^{\circ} \mathrm{C}$. The SOFC air mole flow rate (stream 'AIR') was calculated and set using a calculator block and a design specification block. The calculator block determines the $\mathrm{O}_{2}$ consumed electrochemically; it then sets the 'CATHODE' block $\mathrm{O}_{2}$ split fraction. The design specification block then varies the 'AIR' stream flow rate until the calculated 'CATHODE' block $\mathrm{O}_{2}$ split fraction equals the desired air utilisation factor $\left(U_{a}\right)$ of $16.7 \%$ [2]. $U_{a}$ is defined as the molar ratio of $\mathrm{O}_{2}$ consumed electrochemically to the total $\mathrm{O}_{2}$ supplied. The equations employed may be found in Doherty et al. $[17,18]$. The cathode air preheat temperature is also $800{ }^{\circ} \mathrm{C}$ and it is heated by the combustion products (stream 11) in the HeatX block 'HEX4'. The SOFC stack exhaust stream 12 is then mixed with the CZ flue stream 'HOTFLU3'.

System performance calculations were performed using Fortran code. The SOFC AC efficiency (lower heating value (LHV) basis) and gasifier cold gas efficiency (CGE) (LHV basis) were determined using:

$$
\begin{aligned}
& \eta_{\text {SOFC }}=P_{\text {el }, A C} /\left(\dot{m}_{\text {fuel }} \cdot L H V_{\text {fuel }}\right) \\
& C G E=\left(\dot{m}_{\text {gas }} \cdot L H V_{\text {gas }}\right) /\left(\dot{m}_{\text {biomass }} \cdot L H V_{\text {biomass }}\right)
\end{aligned}
$$

Where $P_{e l, A C}$ is the AC power in $\mathrm{kW}$ (i.e. DC power $\times$ inverter efficiency of $92 \%$ ), $\dot{m}_{f u e l}$ is the 'SYNGAS2' stream mass flow rate in $\mathrm{kg} \mathrm{s}^{-1}, L H V_{\text {fuel }}$ is the lower heating value of the 'SYNGAS2' stream in $\mathrm{kJ} \mathrm{kg}^{-1}, \dot{m}_{g a s}$ and $\dot{m}_{\text {biomass }}$ are the mass flow rate in $\mathrm{kg} \mathrm{s}^{-1}$ of syngas and biomass respectively and $L H V_{\text {gas }}$ and $L H V_{\text {biomass }}$ are the lower heating value in $\mathrm{kJ} \mathrm{kg}^{-1}$ of the syngas and biomass respectively. The plant net AC electrical efficiency (LHV basis) and plant net AC CHP efficiency (LHV basis) were calculated as follows: 


$$
\begin{aligned}
& \eta_{e l, \text { net }}=\left(P_{e l, A C}-P_{\text {parasitic }}\right) / P_{\text {biomass }} \\
& \eta_{C H P, \text { net }}=\left(\left(P_{e l, A C}-P_{\text {parasitic }}\right)+Q\right) / P_{\text {biomass }}
\end{aligned}
$$

Where $P_{\text {parasitic }}$ is the total parasitic power in $\mathrm{kW}$ (includes all compressors, 'PUMP1' and 'PUMP2'), $P_{\text {biomass }}$ is biomass input power in $\mathrm{kW}$ (i.e. $\left.\dot{m}_{\text {biomass }} \times L H V_{\text {biomass }}\right)$ and $Q$ is the maximum recoverable heat in $\mathrm{kW}$.

System 1 performance was lower than anticipated (see Table 1 ) with $\eta_{e l, \text { net }}=25.3 \%$ and $\eta_{C H P, \text { net }}=69.5 \%$. Alternative system layouts were investigated in an attempt to increase performance.

\section{Table 1}

\begin{tabular}{|c|c|c|c|c|}
\hline $\begin{array}{l}\text { Operating Parameter/ } \\
\text { Performance Indicator }\end{array}$ & System 1 & System 2 & System 3 & System 4 \\
\hline SOFC STCR & 4.57 & 2.50 & 2.50 & 4.63 \\
\hline Current density & $1959 \mathrm{~A} \mathrm{~m}^{-2}$ & $1909 \mathrm{~A} \mathrm{~m}^{-2}$ & $1844 \mathrm{~A} \mathrm{~m}^{-2}$ & $1962 \mathrm{~A} \mathrm{~m}^{-2}$ \\
\hline Cell voltage & $0.638 \mathrm{~V}$ & $0.654 \mathrm{~V}$ & $0.677 \mathrm{~V}$ & $0.637 \mathrm{~V}$ \\
\hline SOFC AC efficiency (LHV basis) & $41.2 \%$ & $42.3 \%$ & $43.7 \%$ & $41.0 \%$ \\
\hline Biomass input power & $350.8 \mathrm{~kW}$ & $341.7 \mathrm{~kW}$ & $330.2 \mathrm{~kW}$ & $363.6 \mathrm{~kW}$ \\
\hline Char split (mass basis) & $13.5 \%$ & $13.5 \%$ & $13.5 \%$ & $16.6 \%$ \\
\hline Gasifier $C G E$ (LHV and mass basis) & $76.2 \%$ & $76.2 \%$ & $76.2 \%$ & $73.8 \%$ \\
\hline Parasitic power & $21.6 \mathrm{~kW}$ & $30.3 \mathrm{~kW}$ & $29.9 \mathrm{~kW}$ & $21.5 \mathrm{~kW}$ \\
\hline Maximum recoverable heat & $155.2 \mathrm{~kW}$ & $162.5 \mathrm{~kW}$ & $140.1 \mathrm{~kW}$ & $169.9 \mathrm{~kW}$ \\
\hline Plant net AC electrical efficiency (LHV basis) & $25.3 \%$ & $23.4 \%$ & $24.4 \%$ & $24.5 \%$ \\
\hline Plant net AC CHP efficiency (LHV basis) & $69.5 \%$ & $71.0 \%$ & $66.8 \%$ & $71.2 \%$ \\
\hline
\end{tabular}

Comparison of system base case results (120 kW DC power).

\subsection{System 2 - cathode recycle}

The standalone SOFC model was run using system 1 conditions and it was discovered that the SOFC operated at reduced efficiency due to high SOFC STCR. The anode recycle, employed for syngas preheating, was identified as the cause. As a result, system 2 with a cathode recycle instead of the anode recycle was investigated. The system 2 Aspen Plus flowsheet and description may be found in the supplementary material.

\subsection{System 3 - no recycle with electric heater}

For system 3 the anode recycle was replaced with an electric heater for preheating the syngas before feeding to the SOFC stack. The recycle process was removed from the system. The system 3 Aspen Plus flowsheet and description may be found in the supplementary material. 


\subsection{System 4 - thermal integration}

Thermal integration of the biomass gasifier and SOFC stack was explored in system 4. The high temperature SOFC flue gas (stream 12), which contains $\sim 15$ volume per cent (vol. \%) $\mathrm{O}_{2}$, was split into two streams with one being fed directly to the gasifier $\mathrm{CZ}$ for char combustion. The gasifier $\mathrm{CZ}$ air preheater 'HEX1' was excluded as the flue gas was already at an elevated temperature; thus, there would be cost advantages to this system configuration. The gasifier will operate at lower efficiency compared to system 1 as the flue gas stream temperature is $100{ }^{\circ} \mathrm{C}$ below the $\mathrm{CZ}$ air temperature of $450{ }^{\circ} \mathrm{C}$ for system 1 (stream 12 versus 'HOTAIR' temperature). The system 4 Aspen Plus flowsheet and description may be found in the supplementary material.

The gasifier and SOFC stack were not thermally integrated in systems 1-3. The only thermal link between them was that heat for steam superheating (gasification and humidification steam) was recovered from the mixed gasifier CZ and SOFC flue gas stream ('MIXEDFLU').

\section{Results and discussion}

\subsection{System comparison}

Table 1 compares system performance for a DC power output of $120 \mathrm{~kW}(110.4 \mathrm{~kW} \mathrm{AC})$. The SOFC STCR is much greater for systems 1 and 4 in comparison to systems 2 and 3, caused by the use of an anode recycle for syngas preheating. An SOFC STCR of 2.50 was chosen for systems 2 and 3; this is a realistic level of syngas humidification to prevent carbon deposition problems [25] and to ensure adequate steam for reforming of hydrocarbons/tars. A low current density and high cell voltage leads to a high SOFC efficiency (determined using Eq. (1)). System 3, which has the lowest current density and highest voltage achieves the greatest SOFC efficiency; followed by systems 2,1 and 4 . These results indicate that the fuel cell performs best without a recycle (system 3) and high SOFC STCR has a significant negative impact for systems 1 and 4.

Biomass input power depends on the efficiency. System 3 has the highest SOFC efficiency and the lowest biomass input power. Char split, i.e. the percentage of char sent to the $\mathrm{CZ}$ of the gasifier, changes only for system 4; this rise in char split causes a decrease in gasifier $C G E$ (calculated using Eq. (2)). The lower temperature of the $\mathrm{CZ}$ oxidant stream $\left(350^{\circ} \mathrm{C}\right)$ has a negative influence on gasifier performance. In addition, the reduced $\mathrm{O}_{2}$ content and presence of $\mathrm{H}_{2} \mathrm{O}$ and $\mathrm{CO}_{2}$ affect performance.

Parasitic power (power requirement of pumps, compressors and electric heater) is greatest for system 2, due to high mass flow rate of SOFC air, followed by system 3 and is much lower for systems 1 and 4 . This 
demonstrates that the cathode recycle and electric heater options are both highly energy intensive. Recoverable heat is highest for systems 2 and 4 resulting from high flue gas temperature.

The plant net efficiencies (determined using Eqs. (3) and (4)) reveal that systems 1 and 4 are more attractive than systems 2 and 3. Systems 2 and 3 have inferior electrical efficiency indicating that the increase in SOFC efficiency is outweighed by the rise in parasitic power making these systems unappealing. The base case system 1 achieves the highest electrical efficiency with a 0.8 percentage point (pp) drop for system 4 resulting from decreased gasifier performance compared to system 1. System 4 exhibits the greatest CHP efficiency and in comparison with other systems there would be cost savings as there is no need for a gasifier oxidant heat exchanger.

To confirm the results in Table 1, current density was varied over a wide range for each system. From analysis of these results, it is concluded that a cathode recycle or an electric heater (system 2 and 3 respectively) is not an attractive alternative to the base case anode recycle system (system 1) over the entire operating $j$ range. In addition, thermal integration (system 4) is deemed attractive. The modest drop in $\eta_{e l, n e t}$ may be offset by the substantial rise in $\eta_{C H P, \text { net }}$ and cost benefit (no 'HEX1').

\subsection{System performance enhancement}

The performance of all systems (systems 1-4) was lower than anticipated and therefore potential improvements to the systems were investigated.

\subsubsection{Lowering syngas preheat temperature}

The syngas preheat temperature (temperature at pre-reformer inlet) was lowered, which in turn decreased the SOFC STCR of systems 1 and 4. All system models (1-4) were run with the syngas preheat temperature reduced from $800{ }^{\circ} \mathrm{C}$ to $700{ }^{\circ} \mathrm{C}$ and the results are presented in Table 2. This drop in preheat temperature caused a reduction in the pre-reformer temperature of $\sim 60^{\circ} \mathrm{C}$ in all cases. A drop in temperature of this magnitude should not lead to any thermal gradient problems in the SOFC stack.

In comparison to the base case results (Table 1), the SOFC STCR for systems 1A and 4A are far below their base case values. Less depleted fuel needs to be recycled to reach the reduced syngas preheat temperature, which means less $\mathrm{H}_{2} \mathrm{O}$ content and thus lower STCR. SOFC STCR was set to 2.285 for systems $2 \mathrm{~A}$ and $3 \mathrm{~A}$ so that the results would be comparable to system 1A. The difference in SOFC STCR for system 4A compared to the other systems is miniscule and may be ignored. SOFC performance improves for all systems (compared to Table 1 
results). Current density drops and voltage and efficiency increase. Systems $1 \mathrm{~A}$ and $4 \mathrm{~A}$ experience the largest improvement as a consequence of the dramatic fall in SOFC STCR. It is worth noting that SOFC performance is very similar for systems $1 \mathrm{~A}, 3 \mathrm{~A}$ and $4 \mathrm{~A}$.

The biomass feed requirement falls for all systems but the drop for systems $2 \mathrm{~A}$ and $3 \mathrm{~A}$ was minimal. There was little change in gasifier performance for system 4A. System 1A and 4A parasitic power decreases slightly because of lower syngas and SOFC air flow rates. System 3A parasitic power drops significantly (less energy needed to preheat the syngas), which leads to large gains in plant efficiencies. The results re-affirm that the anode recycle is the better option, in comparison to an electric heater, for syngas preheating. Although the gap in performance between the two is narrowed when syngas preheat temperature is lowered. System $3 \mathrm{~A}$ would be appealing if it was desirable to reduce system complexity, i.e. by removal of the recycle.

Systems 1 and 4 are the most attractive with respect to plant efficiency. System $1 \mathrm{~A}$ achieves the highest electrical efficiency while system 4A has the greatest CHP efficiency (excluding system 2A, which is not considered due to its low $\left.\eta_{e l, n e t}\right)$. In comparison to the base case results in Table 1 , system $1 \eta_{e l, \text { net }}$ and $\eta_{C H P, \text { net }}$ both rise $2 \mathrm{pp}$ and system $4 \eta_{e l, n e t}$ and $\eta_{C H P, \text { net }}$ increase 1.9 and $2 \mathrm{pp}$ respectively. Based on these results, lowering the syngas preheat temperature to improve plant performance is highly recommended.

\section{Table 2}

System performance enhancement: effect of lowering syngas preheat temperature (120 kW DC power).

\begin{tabular}{|c|c|c|c|c|}
\hline $\begin{array}{l}\text { Operating Parameter/ } \\
\text { Performance Indicator }\end{array}$ & System 1A & System 2A & System 3A & System 4A \\
\hline SOFC STCR & 2.285 & 2.285 & 2.285 & 2.277 \\
\hline Current density & $1844 \mathrm{~A} \mathrm{~m}^{-2}$ & $1903 \mathrm{~A} \mathrm{~m}^{-2}$ & $1840 \mathrm{~A} \mathrm{~m}^{-2}$ & $1842 \mathrm{~A} \mathrm{~m}^{-2}$ \\
\hline Cell voltage & $0.677 \mathrm{~V}$ & $0.656 \mathrm{~V}$ & $0.679 \mathrm{~V}$ & $0.678 \mathrm{~V}$ \\
\hline SOFC AC efficiency (LHV basis) & $43.8 \%$ & $42.4 \%$ & $43.8 \%$ & $43.7 \%$ \\
\hline Biomass input power & $330.1 \mathrm{~kW}$ & $340.8 \mathrm{~kW}$ & $329.5 \mathrm{~kW}$ & $342.2 \mathrm{~kW}$ \\
\hline Char split (mass basis) & $13.5 \%$ & $13.5 \%$ & $13.5 \%$ & $16.8 \%$ \\
\hline Gasifier $C G E$ (LHV and mass basis) & $76.2 \%$ & $76.2 \%$ & $76.2 \%$ & $73.6 \%$ \\
\hline Parasitic power & $20.3 \mathrm{~kW}$ & $30.3 \mathrm{~kW}$ & $22.6 \mathrm{~kW}$ & $20.2 \mathrm{~kW}$ \\
\hline Maximum recoverable heat & $145.8 \mathrm{~kW}$ & $173.3 \mathrm{~kW}$ & $141.7 \mathrm{~kW}$ & $160.3 \mathrm{~kW}$ \\
\hline Plant net AC electrical efficiency (LHV basis) & $27.3 \%$ & $23.5 \%$ & $26.7 \%$ & $26.4 \%$ \\
\hline Plant net AC CHP efficiency (LHV basis) & $71.5 \%$ & $74.3 \%$ & $69.7 \%$ & $73.2 \%$ \\
\hline
\end{tabular}

\subsubsection{Lowering syngas and cathode air preheat temperature}

The cathode preheat temperature was also lowered to $700{ }^{\circ} \mathrm{C}$ from $800{ }^{\circ} \mathrm{C}$ in an attempt to increase system 4 gasifier performance. Reducing cathode preheat temperature results in a higher SOFC stack flue gas temperature and therefore gasifier oxidant temperature (increases from 351 to $445.6{ }^{\circ} \mathrm{C}$ ). It will result in a large temperature 
difference between cathode outlet and inlet $\left(910{ }^{\circ} \mathrm{C}-700{ }^{\circ} \mathrm{C}=210^{\circ} \mathrm{C}\right)$, which could cause damaging thermal gradients within the SOFC stack.

Comparing the results displayed in Table 3 with those in Table 2, SOFC performance improves for all systems. SOFC efficiencies for systems $1 \mathrm{~B}, 3 \mathrm{~B}$ and $4 \mathrm{~B}$ were within $0.1 \mathrm{pp}$ of each other. Biomass feed requirement decreases for all systems with the drop for system 4B well above the other systems (11.0 kW versus $\sim 6.7 \mathrm{~kW})$. This was found to be attributable to better gasifier performance; the drop in cathode preheat temperature causes the gasifier $C G E$ to rise from $73.6 \%$ to $74.6 \%$. The increase in $C G E$ was found to be due to the higher $\mathrm{CZ}$ oxidant temperature, which decreases the char required to $15.6 \%$. Once more, systems 1 and 4 perform best; with system $1 \mathrm{~B}$ achieving the highest $\eta_{e l, \text { net }}$ and system $4 \mathrm{~B}$ having the best $\eta_{C H P, \text { net }}$ (system $2 \mathrm{~B}$ excluded). The enormous increase in $\eta_{C H P \text {, net }}$ for all systems is caused by the higher flue gas temperature (less heat removed from flue gas to preheat the cathode air). System 4B experiences the largest rise in $\eta_{e l, \text { net }} ; 1 \mathrm{pp}$ compared to $\sim 0.6 \mathrm{pp}$ for other systems.

\section{Table 3}

System performance enhancement: effect of lowering syngas and cathode air preheat temperature (120 kW DC power).

\begin{tabular}{|c|c|c|c|c|}
\hline $\begin{array}{l}\text { Operating Parameter/ } \\
\text { Performance Indicator }\end{array}$ & System 1B & System 2B & System 3B & System 4B \\
\hline SOFC STCR & 2.285 & 2.285 & 2.285 & 2.280 \\
\hline Current density & $1808 \mathrm{~A} \mathrm{~m}^{-2}$ & $1863 \mathrm{~A} \mathrm{~m}^{-2}$ & $1805 \mathrm{~A} \mathrm{~m}^{-2}$ & $1807 \mathrm{~A} \mathrm{~m}^{-2}$ \\
\hline Cell voltage & $0.691 \mathrm{~V}$ & $0.671 \mathrm{~V}$ & $0.692 \mathrm{~V}$ & $0.691 \mathrm{~V}$ \\
\hline SOFC AC efficiency (LHV basis) & $44.6 \%$ & $43.3 \%$ & $44.7 \%$ & $44.6 \%$ \\
\hline Biomass input power & $323.7 \mathrm{~kW}$ & $333.5 \mathrm{~kW}$ & $323.1 \mathrm{~kW}$ & $331.2 \mathrm{~kW}$ \\
\hline Char split (mass basis) & $13.5 \%$ & $13.5 \%$ & $13.5 \%$ & $15.6 \%$ \\
\hline Gasifier $C G E$ (LHV and mass basis) & $76.2 \%$ & $76.2 \%$ & $76.2 \%$ & $74.6 \%$ \\
\hline Parasitic power & $19.9 \mathrm{~kW}$ & $29.6 \mathrm{~kW}$ & $22.2 \mathrm{~kW}$ & $19.8 \mathrm{~kW}$ \\
\hline Maximum recoverable heat & $189.3 \mathrm{~kW}$ & $232.9 \mathrm{~kW}$ & $185.1 \mathrm{~kW}$ & $198.4 \mathrm{~kW}$ \\
\hline Plant net AC electrical efficiency (LHV basis) & $27.9 \%$ & $24.2 \%$ & $27.3 \%$ & $27.4 \%$ \\
\hline Plant net AC CHP efficiency (LHV basis) & $86.4 \%$ & $94.1 \%$ & $84.6 \%$ & $87.3 \%$ \\
\hline
\end{tabular}

Considering these results, it appears that lowering the syngas preheat temperature is the better option for enhancing system performance as it has a strong positive impact and it only results in an anode temperature drop of $60{ }^{\circ} \mathrm{C}$ and therefore is not as likely to cause dangerous temperature gradients within the SOFC stack. 


\subsection{Parametric study}

Sensitivity analyses of the main operating parameters were carried out for the best performing system configuration (without performance enhancement measures), i.e. system 1. The results presented and discussed in this section were attained using the system 1 model (exception: system 3 layout employed for cleaning temperature sensitivity at high cleaning temperature $600-700{ }^{\circ} \mathrm{C}$ as recycle was not required).

\subsubsection{Current density}

Referring to Fig. $4, j$ was varied from 110 to $420 \mathrm{~mA} \mathrm{~cm}^{-2}$ and it was found to have significant influence on the system. Cell voltage and efficiency decrease $(0.746-0.284 \mathrm{~V}$ and $48.1-18.4 \%$ respectively) and power increases to a peak, after which it drops. This indicates that there must be a trade-off between SOFC voltage, power and efficiency. Increasing $j$ has a strong negative impact on plant performance, net electrical and CHP efficiencies fall $\sim 23$ pp over the $j$ range. This drop is due to higher parasitic power and biomass input. It is clear from Fig. 4 (b) that the parasitic power is dominated by the syngas compressor power requirement. The syngas compressor must compress a gas at $400{ }^{\circ} \mathrm{C}$ to three times the SOFC pressure; whereas the SOFC air compressor only raises the air pressure to 1.094 bar and the air inlet temperature is low at $25^{\circ} \mathrm{C}$. The results over a typical operating $j$ range of $180-200 \mathrm{~mA} \mathrm{~cm}^{-2}$, indicate a cell voltage range of $0.658-0.632 \mathrm{~V}, \eta_{e l, n e t}$ range of $26.3-25.1 \%$, $\eta_{C H P, n e t}$ range of 70.6-69.3\% and a DC power range of 113.8-121.5 kW.
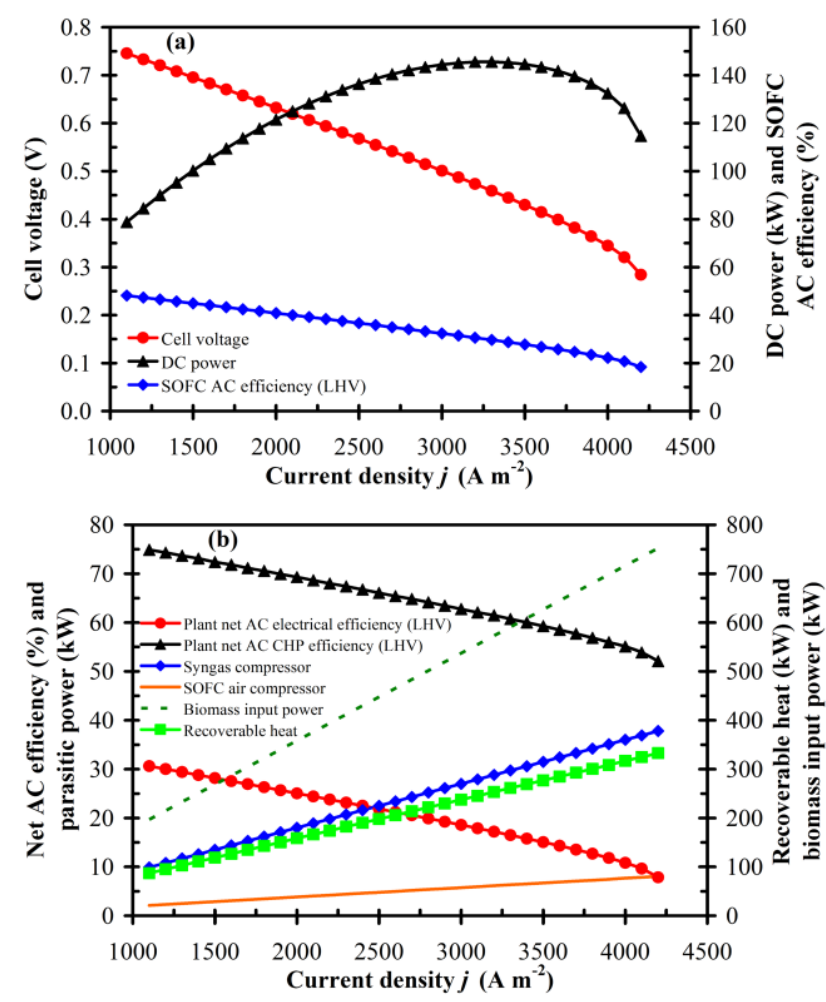

Fig. 4. Effect of current density on system 1. 


\subsubsection{Steam to carbon ratio}

The effects of varying STCR are depicted in Fig. 5. From Fig. 5 (a) it can be seen that STCR has a substantial negative impact on voltage (0.647-0.573 V) and SOFC efficiency (41.8-37.0\%) and increases current density (193-218 $\left.\mathrm{mA} \mathrm{cm}^{-2}\right)$, this is due to the change in gaseous component partial pressures $\left(\mathrm{H}_{2} \mathrm{O}\right.$ rises, $\mathrm{H}_{2}$ and $\mathrm{CO}$ fall). This leads to a drop in Nernst voltage $(0.887-0.850 \mathrm{~V})$ and an increase in voltage losses. Fig. 5 (b) shows that more biomass fuel is required to achieve $120 \mathrm{~kW} \mathrm{DC,} \mathrm{which} \mathrm{increases} \mathrm{parasitic} \mathrm{power} \mathrm{due} \mathrm{to} \mathrm{greater} \mathrm{mass} \mathrm{flow}$ rates, and decreases the plant net efficiencies significantly ( $\eta_{e l, n e t}$ down $6.7 \mathrm{pp}$ and $\eta_{C H P, \text { net }}$ drops $\left.14.7 \mathrm{pp}\right)$. Recoverable heat decreases because the steam requirement rises, lowering the plant flue gas temperature. It is therefore desirable to operate the plant at low STCR.
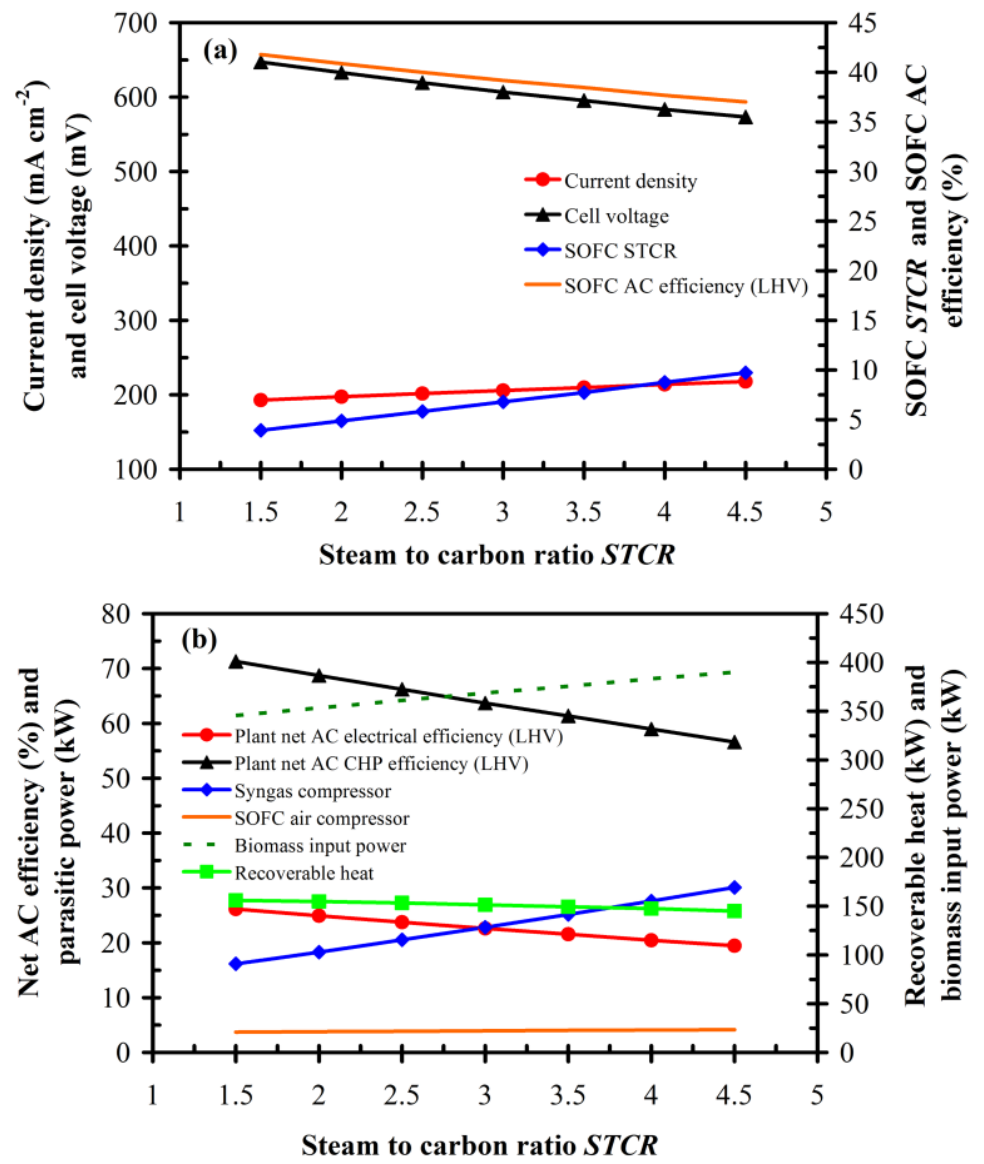

Fig. 5. Effect of steam to carbon ratio on system 1.

\subsubsection{Fuel utilisation factor}

Fuel utilisation factor $\left(U_{f}\right)$ is defined as the molar ratio of $\mathrm{H}_{2}$ consumed electrochemically to the total $\mathrm{H}_{2}$ supplied. The influence of $U_{f}$ on system 1 performance is illustrated in Fig. 6. The SOFC performance results are 
not presented but will be discussed. Voltage decreases slightly with $U_{f}$ due to increased losses and current density increases $\sim 15 \mathrm{~mA} \mathrm{~cm}{ }^{-2}$. $\eta_{\text {SOFC }}$ displays a huge increase $(28.8-41.1 \%)$ attributable to the dramatic drop in the biomass input required to achieve the desired power (120 kW DC). This is because more of the energy contained in the fuel is converted to electricity rather than heat (un-reacted fuel is burned in the SOFC post combustor 'POSTCOMB'). Plant efficiencies are very sensitive to changes in $U_{f}$, $\eta_{e l, \text { net }}$ increases by 9 pp and $\eta_{C H P, \text { net }}$ drops $14.2 \mathrm{pp}$. The increase in $\eta_{e l, n e t}$ is primarily due to the reduced biomass input at high $U_{f}$. At low $U_{f}$ more of the fuel is available for combustion therefore the SOFC stack flue temperature is high and as $U_{f}$ increases the temperature drops, thus lowering the recoverable heat and $\eta_{C H P, \text { net }}$. The influence of $U_{f}$ on anode feed gas composition (wet basis (wb)) is shown in Fig. 6 (b). Higher $U_{f}$ results in greater levels of $\mathrm{H}_{2} \mathrm{O}$ and $\mathrm{CO}_{2}$ and lower $\mathrm{H}_{2}$ and $\mathrm{CO}$. This causes the slight drop in cell voltage $(\sim 15 \mathrm{mV})$. It is recommended to operate the SOFC stack at high $U_{f}$ as it is usually desirable to run the plant at high $\eta_{e l, n e t}$ rather than high $\eta_{C H P, \text { net }}$. These results reveal $U_{f}$ as an extremely important operating parameter as it can change the mode of operation of the plant (focus on electricity or heat).
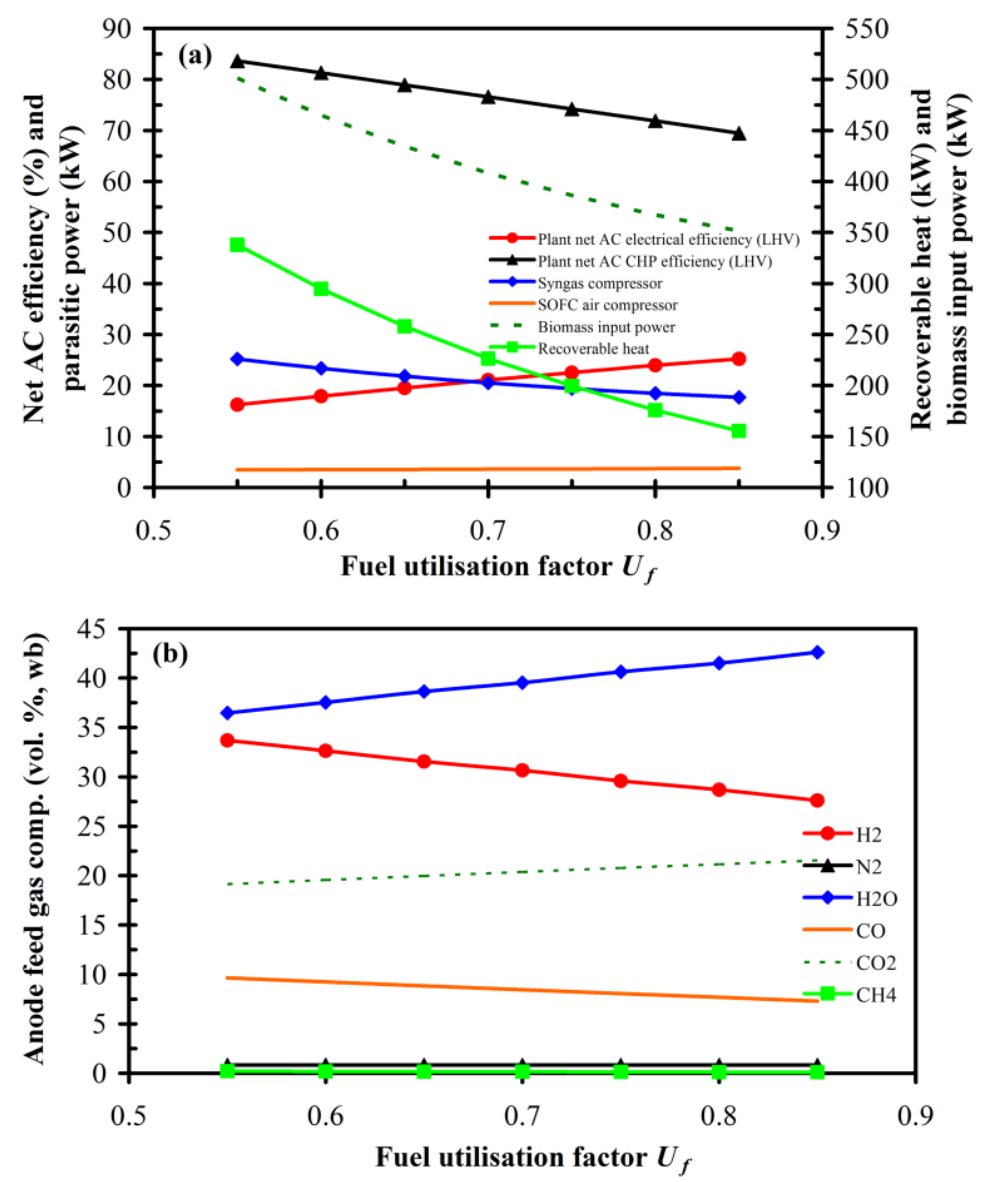

Fig. 6. Effect of fuel utilisation factor on system 1 . 


\subsubsection{Gasification temperature}

Gasification temperature is the temperature in the $\mathrm{GZ}$ of the DFB gasifier (recall the $\mathrm{CZ}$ temperature is $70{ }^{\circ} \mathrm{C}$ above $T_{g}$ ). Fig. 7 (a) displays how $T_{g}$ affects the LHV of the syngas (dry basis (db)), gasifier $C G E$ and the char split fraction. It is evident that $T_{g}$ has significant influence on gasifier performance. LHV increases from 14.1 to 15.2 $\mathrm{MJ} \mathrm{kg}^{-1}$ and the char split fraction climbs from $11.3 \%$ to $19.0 \%$. Gasifier $C G E$ rises from $72.5 \%$, reaches a peak of $79.9 \%$ at $950{ }^{\circ} \mathrm{C}$ and falls to $78.6 \%$. These trends are in line with the changes in syngas composition; $\mathrm{H}_{2}$ and $\mathrm{CO}$ rise and $\mathrm{H}_{2} \mathrm{O}, \mathrm{CO}_{2}$ and $\mathrm{CH}_{4}$ decrease. Therefore, it is concluded that increasing $T_{g}$ has a favourable influence on gasifier performance.
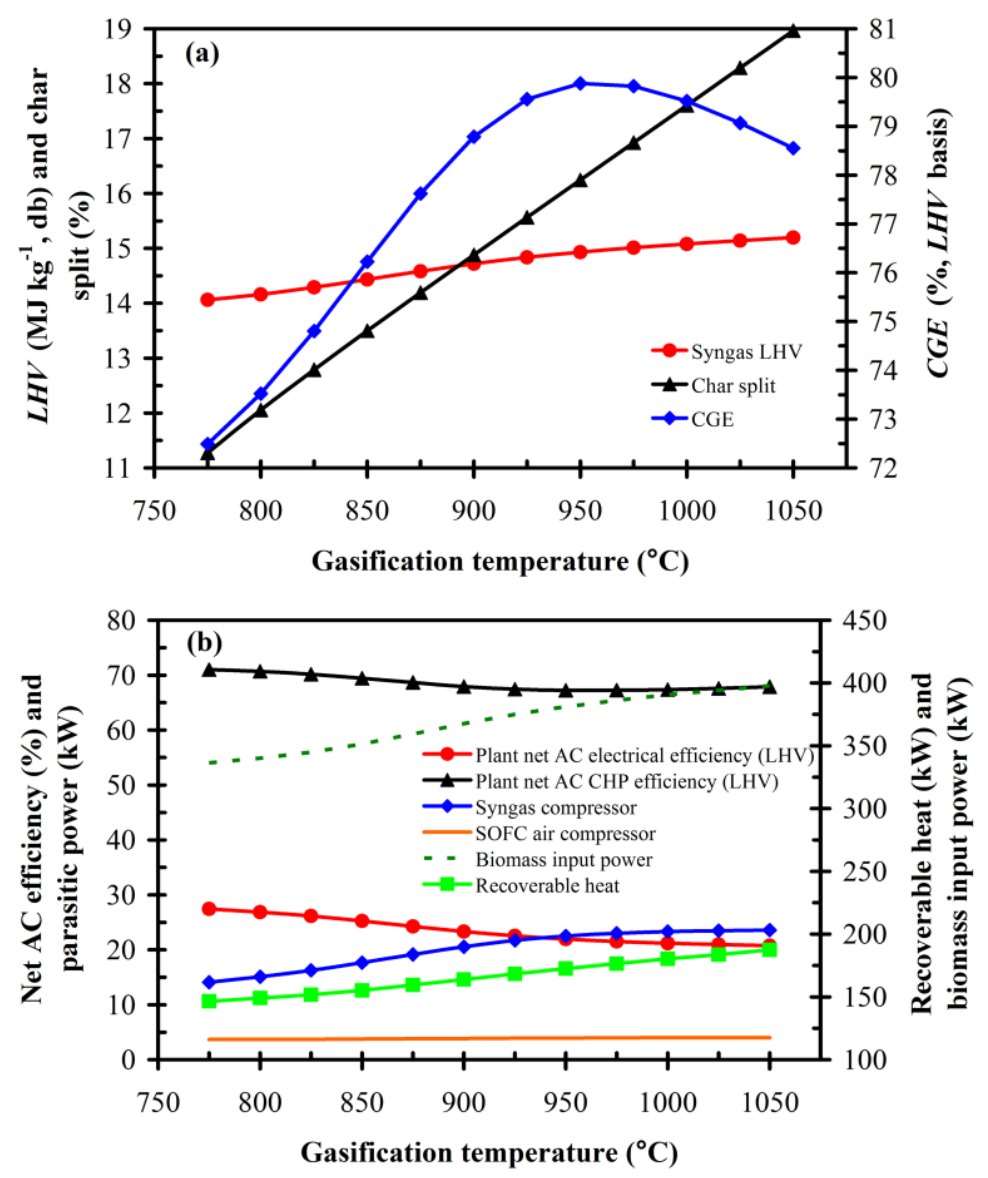

Fig. 7. Effect of gasification temperature on system 1.

A somewhat surprising conclusion is drawn from analysis of the SOFC stack and overall plant performance results; these results suggest that $T_{g}$ should be kept as low as possible. This was surprising considering the gasifier performance drops with decreasing $T_{g}$. From Fig. 7 (b) it can be seen that $T_{g}$ has a considerable negative impact on $\eta_{e l, \text { net }}\left(\right.$ down $6.7 \mathrm{pp}$ ) and a lesser influence on $\eta_{C H P \text {,net }}($ down $3.1 \mathrm{pp})$. These trends can be explained by 
the fact that biomass input climbs from $336.5 \mathrm{~kW}$ to $397.8 \mathrm{~kW}$ and parasitic power also rises due to higher mass flow rates. Further investigation revealed the reason for the SOFC performance degradation. When the low $\mathrm{CH}_{4}$ content syngas (obtained at high $T_{g}$ ) is fed to the SOFC pre-reformers, the conditions favour the reverse CO-shift reaction $\left(\mathrm{CO}_{2}+\mathrm{H}_{2} \rightleftharpoons \mathrm{CO}+\mathrm{H}_{2} \mathrm{O}\right)$. This reaction is favoured because of the rising pre-reformer temperature

(586.4-822.4 ${ }^{\circ} \mathrm{C}$ ), which is due to the low level of $\mathrm{CH}_{4}$ reforming (endothermic). $\mathrm{H}_{2} \mathrm{O}$ content in the anode feed gas increases and leads to lower SOFC stack performance.

The results suggest that $T_{g}$ should be kept as low as possible with respect to SOFC stack and overall plant performance. However, a low $T_{g}$ would lead to high tar levels in the syngas, which could cause severe damage to the SOFC stack. Considering these findings, it is recommended to operate the gasifier in the $T_{g}$ range $850-900{ }^{\circ} \mathrm{C}$ in order to produce a high energy content syngas with high $\mathrm{H}_{2}$ and $\mathrm{CO}$, to achieve acceptable gasifier $C G E$, to ensure a safe level of tars for conversion in the SOFC stack and to achieve reasonable plant efficiency.

\subsubsection{Biomass moisture content}

Biomass moisture content has little impact on syngas composition. The effect of increasing moisture content on LHV of the syngas, gasifier CGE and the char split fraction is illustrated in Fig. 8. It has little effect on LHV (depends on the gas composition). However, it has a very strong influence on $C G E$ (decreases from $93.6 \%$ at $5 \%$ moisture to $64.7 \%$ at $30 \%$ moisture). This influence on $C G E$ may be explained by the increase in char split fraction with rising moisture (10.2-16.5\%). Moisture content has little effect on SOFC stack performance (current, voltage and $\eta_{S O F C}$ remain fairly constant). Fig. 8 (b) reveals that moisture has a strong unfavourable effect on the plant net efficiencies ( $\eta_{e l, n e t}$ down $9.8 \mathrm{pp}$ and $\eta_{C H P, \text { net }}$ drops $18.6 \mathrm{pp}$ ). At a low moisture content of $5 \%$ the predicted efficiencies are very high at $31.2 \%$ and $80.7 \%$ for $\eta_{e l, \text { net }}$ and $\eta_{C H P \text {,net }}$ respectively. As parasitic power remains constant, the change in plant efficiencies is due to the rise in biomass input power (285.1-414.8 $\mathrm{kW}$ ). Based on these results, the biomass moisture content is an operating parameter of extreme importance and should be as low as possible, i.e. the biomass fuel should be dried prior to use in the gasifier. At sufficient scale, investment in a biomass dryer is recommended as it is prohibitively expensive to purchase biomass that has been dried to low moisture $(<\sim 15 \%)$. 

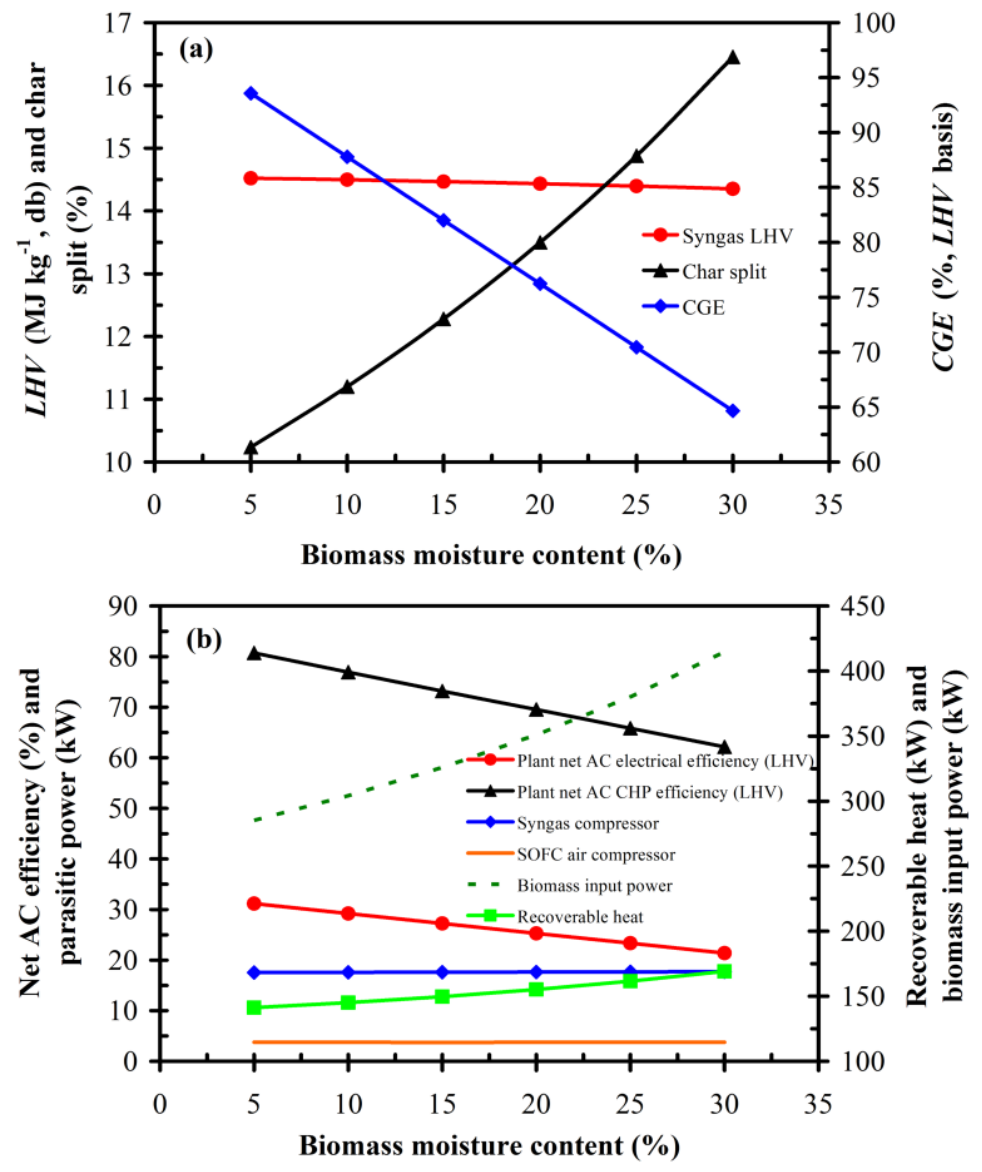

Fig. 8. Effect of biomass moisture content on system 1 .

\subsubsection{Syngas cleaning temperature}

Cleaning temperature will be a function of the type of technology employed but for the purposes of this investigation a temperature range of $400-700{ }^{\circ} \mathrm{C}$ was assumed. The base case system 1 configuration was employed for the cleaning temperature range of $400-500{ }^{\circ} \mathrm{C}$ but for higher temperatures $\left(600{ }^{\circ} \mathrm{C}\right.$ and $\left.700{ }^{\circ} \mathrm{C}\right)$ system 3 plant layout was utilised as the anode recycle was no longer a practical method for syngas preheating. The 'COMP1' block power requirement to compress the syngas at $600-700{ }^{\circ} \mathrm{C}$ to three times the SOFC pressure was too high and made cleaning at high temperature unattractive (high parasitic power reduced $\eta_{e l, n e t}$ ). In addition, the syngas temperature after compression was above $800{ }^{\circ} \mathrm{C}$; making the anode recycle redundant (purpose of recycle was to raise syngas temperature to $800{ }^{\circ} \mathrm{C}$ ). The use of an electric heater for syngas preheating as in system 3 was more efficient for these temperatures. At $600-700{ }^{\circ} \mathrm{C}$ when the system 3 configuration was employed the STCR was increased to 2.285 in order to make results comparable with the system 1 results (at $400-500{ }^{\circ} \mathrm{C}$ ). 
The effect of raising the operating temperature of the syngas cleaning system on SOFC stack and plant performance is illustrated in Fig. 9. SOFC stack performance improves with $\eta_{S O F C}$ increasing from $41.2 \%$ to 44.0\%. This rise is due to a drop in required biomass feed and a rise in cell voltage $(0.637-0.680 \mathrm{~V})$. Plant net efficiencies display a strong dependence on cleaning temperature. $\eta_{\text {el,net }}$ increases 5 pp (25.3\% to $\left.30.3 \%\right)$ and $\eta_{C H P, \text { net }}$ falls $2.5 \mathrm{pp}(69.5 \%$ to $67.0 \%)$. For $500{ }^{\circ} \mathrm{C}$, the rise in electrical efficiency is put down to the drop in SOFC STCR (less depleted fuel needs to be recycled to achieve the preheat temperature) and the resulting improved SOFC stack performance and also the fall in biomass input power. For $600-700{ }^{\circ} \mathrm{C}$, the improvement in $\eta_{e l, n e t}$ is due to the fall in parasitic power; i.e. the syngas compressor power requirement decreases from $\sim 18.0$ $\mathrm{kW}$ to $\sim 1.7 \mathrm{~kW}$ (syngas is compressed to 1.094 bar instead of $3.282 \mathrm{bar}$ ). Contrasting the results at $600{ }^{\circ} \mathrm{C}$ and $700{ }^{\circ} \mathrm{C}$ the rise in $\eta_{e l, n e t}$ is because of the reduction in syngas electric heater power $(11.8-5.2 \mathrm{~kW})$. The decrease in $\eta_{C H P, \text { net }}$ is caused by a significant drop in recoverable heat $(155.0-120.5 \mathrm{~kW})$. Less heat can be recovered at high cleaning temperature as less heat is taken from the syngas cooling section of the plant, which leads to more heat being removed from the 'MIXEDFLU' stream for steam generation in the 'HEX3' block.
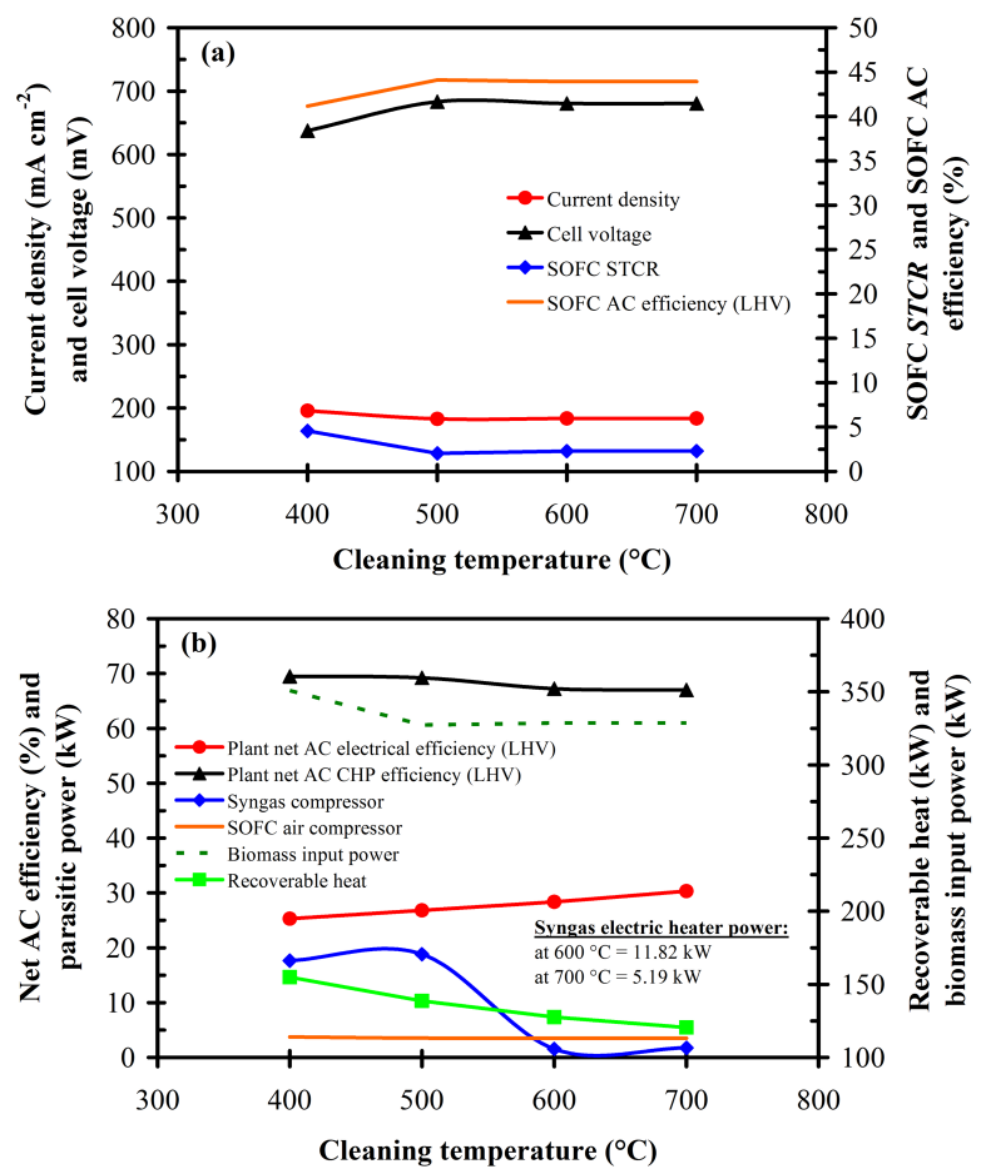

Fig. 9. Effect of cleaning temperature on system performance. 
The increase in voltage is caused by a rise in Nernst voltage (due to variation in anode feed gas composition) and a fall in voltage losses. The cause of the change in anode feed gas composition is the change in SOFC STCR. At $400{ }^{\circ} \mathrm{C}$ SOFC STCR $=4.57$ and $\mathrm{H}_{2} \mathrm{O}$ and $\mathrm{CO}_{2}$ are high, which results in low $\mathrm{H}_{2}$ and CO. For 500-700 ${ }^{\circ} \mathrm{C}$, SOFC STCR is lower (2.040-2.285), which leads to higher $\mathrm{H}_{2}$ and $\mathrm{CO}$ and lower $\mathrm{H}_{2} \mathrm{O}$ and $\mathrm{CO}_{2}$. These changes in composition lead to better SOFC stack performance.

In summary, the improvement in plant performance with rising syngas cleaning temperature is due to the reduction in SOFC STCR (less recirculation required to achieve the syngas preheat temperature) and parasitic power (no recycle needed at high cleaning temperature and therefore syngas compressor power drops dramatically).

In conclusion, high temperature syngas cleaning appears to be very attractive as it offers the potential to reduce plant complexity (no need for an anode recycle) and improves the performance of the SOFC stack and net electrical efficiency of the plant significantly. However, there are limits on the currently available cleaning technologies. The maximum operating temperature for $\mathrm{HCl}$ removal to $1 \mathrm{ppmv}$ in a sodium carbonate bed is 600 ${ }^{\circ} \mathrm{C}$ [23]. The maximum operating temperature for $\mathrm{H}_{2} \mathrm{~S}$ removal to $<1 \mathrm{ppmv}$ in a $\mathrm{ZnO}$ bed is $\sim 400{ }^{\circ} \mathrm{C}[3,4,23]$. Research efforts should continue in order to increase the temperature of syngas cleaning so that the improvements in efficiency predicted here may be realised. Finally, for a cleaning temperature of $700{ }^{\circ} \mathrm{C}$ and a syngas preheat temperature of $700{ }^{\circ} \mathrm{C}$ (lowered from $800{ }^{\circ} \mathrm{C}$ ) the electric heater power requirement of $5.2 \mathrm{~kW}$ could be eliminated, resulting in a further increase in $\eta_{e l, n e t}(30.3 \%$ to $\sim 31.9 \%)$. This demonstrates the great potential that BG-SOFC systems have for achieving high operating efficiency. In contrast, biomass combustion based technologies achieve low electrical efficiencies at small scale (20-25\%).

\subsubsection{Other operating parameters}

The influence of gasification steam and gasifier $\mathrm{CZ}$ air temperature was also studied. Gasification steam temperature has little impact on plant performance $\left(\eta_{\text {el,net }}\right.$ rises $0.2 \mathrm{pp}$ and $\eta_{C H P \text {,net }}$ drops $0.4 \mathrm{pp}$ over the temperature range $160-350^{\circ} \mathrm{C}$ ). Considering these results, it may be desirable to simplify the plant and achieve cost savings by removing the steam superheater ('HEX3') from the system. $\eta_{e l, \text { net }}$ and $\eta_{C H P, \text { net }}$ have weak dependence on gasification air temperature; increasing 1.1 and decreasing $2.1 \mathrm{pp}$ respectively over the temperature range $25-650^{\circ} \mathrm{C}$. It is concluded that gasification air preheating is more attractive than gasification steam superheating. Over the temperature range $160-350{ }^{\circ} \mathrm{C}$, air preheating raises $\eta_{e l, n e t}$ and $C G E 0.4$ and $1 \mathrm{pp}$ respectively, whereas steam superheating increases $\eta_{e l, n e t}$ and $C G E$ only 0.2 and 0.7 pp respectively. 


\section{Conclusions}

The process simulation software package Aspen Plus was employed to develop models of various BG-SOFC system configurations. The aim of the research work, which was to investigate the technical feasibility of BGSOFC CHP systems and to study the influence of important operating parameters and examine integration options, was achieved.

Four system configurations were investigated; system 1 (base case with anode recycle), system 2 (cathode recycle), system 3 (no recycle with an electric heater used for syngas preheating) and system 4 (thermal integration). The results revealed that a cathode recycle or electric heater is not an attractive alternative to the base case anode recycle system for syngas preheating. In addition, thermal integration between the gasifier and SOFC is attractive. Lowering the syngas preheat temperature is highly recommended and was found to be more practical than lowering the cathode air preheat temperature.

The effects of varying $j$, STCR, $U_{f}, T_{g}$, biomass moisture content, syngas cleaning temperature and gasification steam and gasifier $\mathrm{CZ}$ air temperature were investigated, the results of which revealed the following:

- STCR has substantial negative impact on SOFC efficiency and plant net efficiencies. It is therefore desirable to operate at low STCR. With an anode recycle, the only way to achieve this is to reduce the syngas preheat temperature.

- $U_{f}$ can change the mode of operation of the plant as it has a very strong influence on the power-to-heat ratio.

- Biomass moisture has a strong unfavourable effect on the plant net efficiencies. Moisture content is of extreme importance and should be as low as possible.

- High temperature syngas cleaning appears to be very attractive as it offers the potential to reduce plant complexity (no need for recycle) and improves performance significantly. Research efforts on hot gas cleaning should continue.

- Gasification air preheating is more attractive than gasification steam superheating.

The main finding is that biomass gasification and solid oxide fuel cell technologies are ideally matched and when integrated have the potential to achieve very high efficiencies (even at small scale). This makes these systems very attractive compared to traditional biomass combustion based systems (only efficient at large scale). High efficiency at small scale is important as scale is limited by biomass supply logistics. CHP plants based on BG-SOFC technology can contribute significantly to EU energy efficiency and high efficiency CHP targets. 


\section{References}

[1] K.D. Panopoulos, L.E. Fryda, J. Karl, S. Poulou, E. Kakaras, Journal of Power Sources, 159 (2006) 570585.

[2] R. Suwanwarangkul, E. Croiset, M.D. Pritzker, M.W. Fowler, P.L. Douglas, E. Entchev, Journal of Power Sources, 166 (2007) 386-399.

[3] R. Toonssen, Sustainable power from biomass, TU Delft, The Netherlands, 2010.

[4] F.-P. Nagel, Electricity from wood through the combination of gasification and solid oxide fuel cells: systems analysis and proof-of-concept, ETH Zurich, Switzerland, 2008.

[5] C. Bang-Møller, M. Rokni, B. Elmegaard, J. Ahrenfeldt, U.B. Henriksen, Energy, 58 (2013) 527-537.

[6] A. Di Carlo, E. Bocci, V. Naso, International Journal of Hydrogen Energy, 38 (2013) 532-542.

[7] M. Morandin, F. Maréchal, S. Giacomini, Biomass and Bioenergy, 49 (2013) 299-314.

[8] P.V. Aravind, T. Woudstra, N. Woudstra, H. Spliethoff, Journal of Power Sources, 190 (2009) 461-475.

[9] M. Sucipta, S. Kimijima, K. Suzuki, Journal of Power Sources, 174 (2007) 124-135.

[10] W. Doherty, Modelling of biomass gasification integrated with a solid oxide fuel cell system, DIT, Ireland, 2014.

[11] G. Schuster, G. Loffler, K. Weigl, H. Hofbauer, Bioresource Technology, 77 (2001) 71-79.

[12] W. Doherty, A. Reynolds, D. Kennedy, Aspen plus simulation of biomass gasification in a steam blown dual fluidised bed, in: A. Méndez-Vilas (Ed.) Materials and processes for energy: communicating current research and technological developments, Formatex Research Centre, 2013.

[13] M. Gariglio, F. De Benedictis, M. Santarelli, M. Calì, G. Orsello, International Journal of Hydrogen Energy, 34 (2009) 4661-4668.

[14] M.C. Williams, J.P. Strakey, S.C. Singhal, Journal of Power Sources, 131 (2004) 79-85.

[15] S.C. Singhal, K. Kendall, High-temperature solid oxide fuel cells: fundamentals, design and applications, Elsevier Advanced Technology, Oxford, 2003.

[16] R.A. George, Journal of Power Sources, 86 (2000) 134-139.

[17] W. Doherty, A. Reynolds, D. Kennedy, Energy, 35 (2010) 4545-4555.

[18] W. Doherty, A. Reynolds, D. Kennedy, Journal of The Electrochemical Society, 157 (2010) B975-B981.

[19] In brief - Siemens to sell off SOFC business. Fuel Cells Bulletin, 2008 (2008) 5-9.

[20] T. Pröll, R. Rauch, C. Aichernig, H. Hofbauer, International Journal of Chemical Reactor Engineering 5(2007) 1-19. 
[21] S. Campanari, Journal of Power Sources, 92 (2001) 26-34.

[22] R. Zwart, Gas Cleaning: Downstream Biomass Gasification-Status Report, ECN, 2009.

[23] P.V. Aravind, W. de Jong, Progress in Energy and Combustion Science, 38 (2012) 737-764.

[24] A. Fuerte, R.X. Valenzuela, M.J. Escudero, L. Daza, Journal of Power Sources, 192 (2009) 170-174.

[25] P. Hofmann, A. Schweiger, L. Fryda, K.D. Panopoulos, U. Hohenwarter, J.D. Bentzen, J.P. Ouweltjes, J. Ahrenfeldt, U. Henriksen, E. Kakaras, Journal of Power Sources, 173 (2007) 357-366. 


\section{Supplementary material}

Only the SOFC stack portion of the Aspen Plus flowsheet is displayed in Fig. 10; the rest of the flowsheet matches that of system 1 (Fig. 3). In this system the 'SYNGAS2' stream is compressed to the SOFC stack pressure (1.094 bar) in the block 'COMP1'. The syngas is then preheated to $790{ }^{\circ} \mathrm{C}$ in the HeatX block 'HEX5'. The syngas preheat temperature is slightly lower than for system 1 as the hot stream (stream 11B) is below 800 ${ }^{\circ} \mathrm{C}$. On the cathode side 'AIR' enters the 'COMP2' block where it is compressed to three times the SOFC stack pressure in order to drive the cathode recycle process. A design specification block controls the amount of cathode off-gas recycled by varying the split fraction of block 'SPLIT' until the stream 15 temperature $=670^{\circ} \mathrm{C}$. The cathode air temperature is brought up to $800{ }^{\circ} \mathrm{C}$ in the 'HEX4' block through heat exchange with the burner exhaust gas (stream 11). All other aspects of the system 2 model match those of the system 1 model.

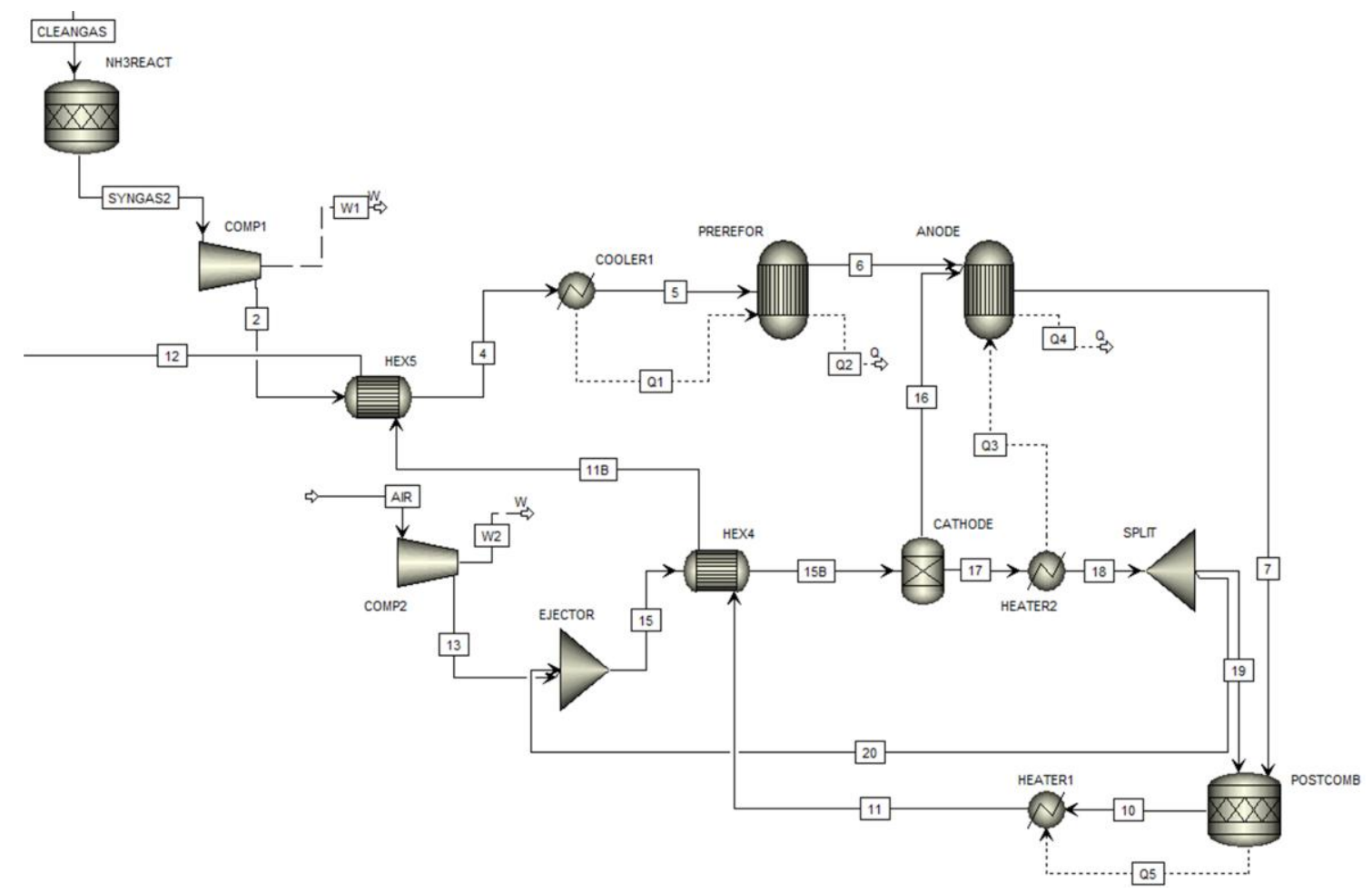

Fig. 10. System 2 Aspen Plus flowsheet. 
Again only the SOFC stack portion of the Aspen Plus flowsheet is displayed in Fig. 11; the rest of the flowsheet matches that of system 1 (Fig. 3). The 'SYNGAS2' stream is fed to block 'COMP1' where the pressure of the fuel is raised to 1.094 bar. The syngas is preheated to the SOFC stack inlet temperature of $800{ }^{\circ} \mathrm{C}$ by means of an electric heater titled 'HEATER3'. The power requirement of the electric heater was calculated $\left(\dot{m} c_{p} \Delta T\right.$ ), which was subsequently included in the system performance calculations (parasitic power and net efficiencies). All other aspects of the system 3 model match those of the system 1 model.

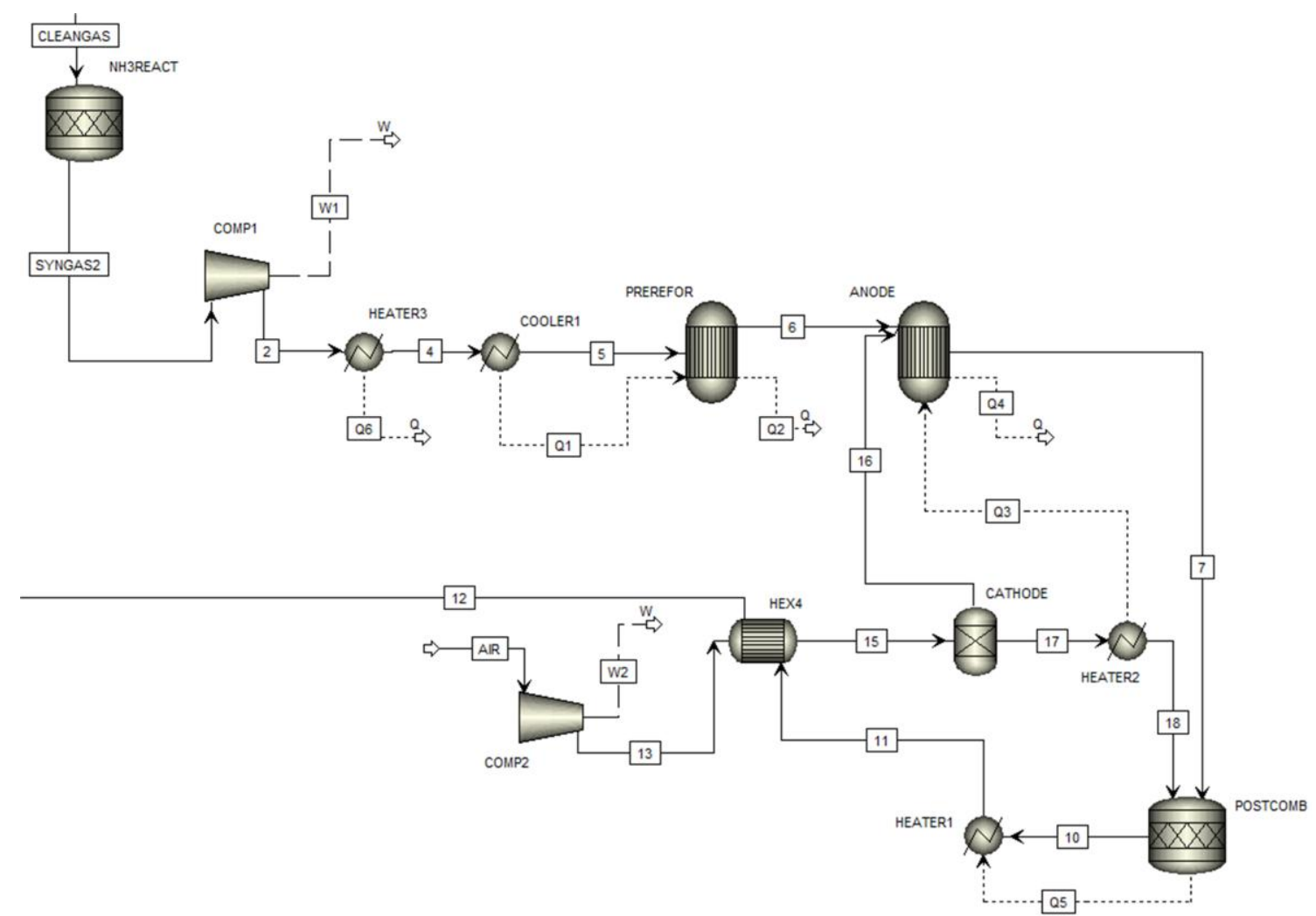

Fig. 11. System 3 Aspen Plus flowsheet.

With reference to Fig. 12, all Aspen Plus unit operation blocks are identical to those of system 1 except for the inclusion of a splitter block 'SPLIT2' and the exclusion of the gasifier CZ air preheater 'HEX1'. The split fraction of block 'SPLIT2' is set by a design specification block assuming a value of $8 \mathrm{~kg} / \mathrm{h}$ for excess $\mathrm{O}_{2}$ in the CZ exhaust (mean value over the SOFC current density range $100-420 \mathrm{~mA} \mathrm{~cm}^{-2}$ for system 1 ). 


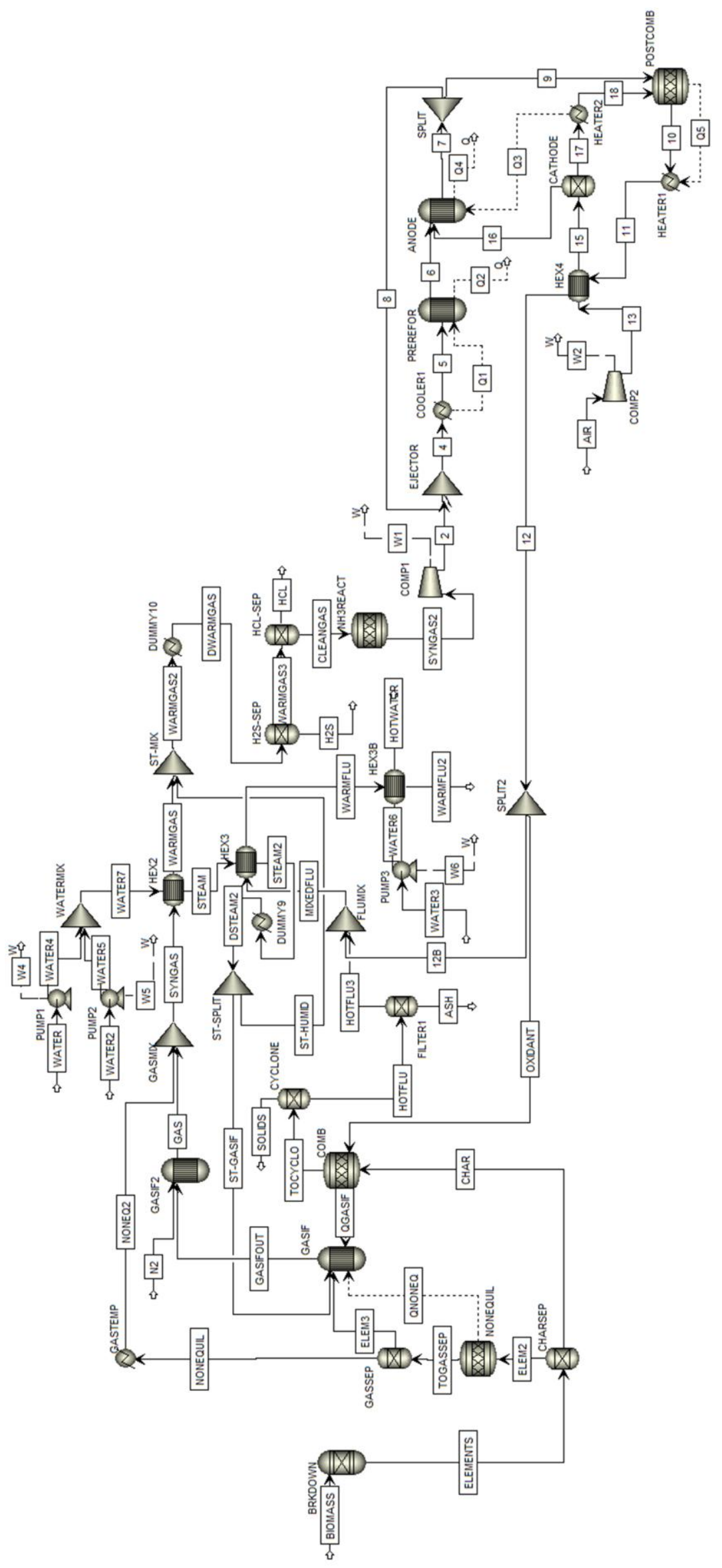

Fig. 12. System 4 Aspen Plus flowsheet. 